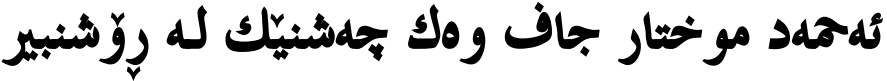

\author{
م.ى. لـهوْن قـادر

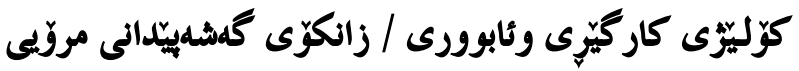

\section{يوختلى باسلكه}

شاعير نويَنهرايلتى بزووتنهوهيهى رِوناكبيرىو ئهدهبى جياوازى كردووه للهيّو رِّوشنبيرانى سهردهمى

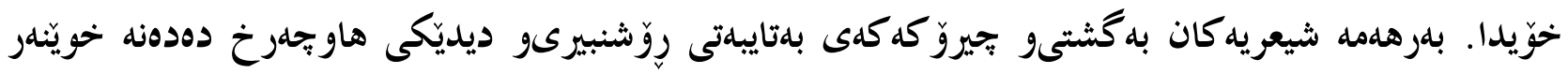

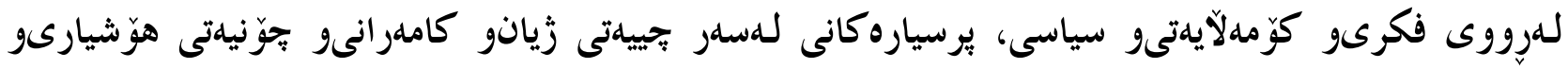
سياسلتى داديلروهر انهو هلروهها باسكردن له وهزيفهى ناينو دهولّلتو گُومان دروستكردن للهسهر خانهدان

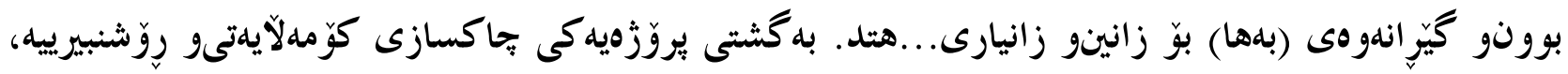

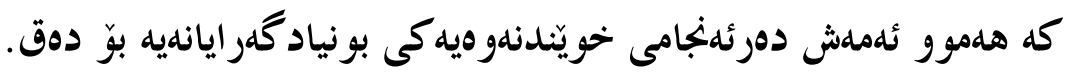

\section{ملغصص البحث}

يمثّلُ الشاعرُ حر كة ثقافية وأدبية متميزة بين مُعاصريِِ مِن المُثقفين. ثُقدِّمُ رِناجاثُه الشعرية بشكلٍ عام و القصصية بشكلٍ خحص وجهة معاصرة للقُّاء من شتى الجو انب الفكرية والاجتماعية و السياسية، إستفساراتلِ حول ماهية الحياة والسعادة وكيفية السبيل إلى الوعي والسياسة العادلة، وتَطُّرِهِ إلى وظيفة الدِّيِِ والدولة،

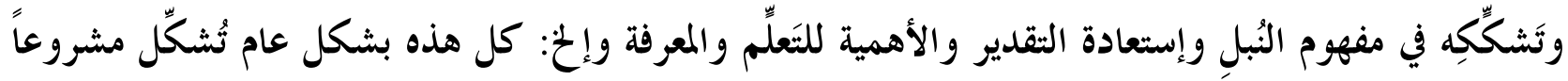

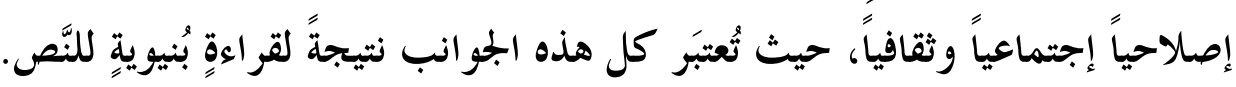

\section{Abstract}

The poet represents a distinctive cultural and literary movement among his contemporary intellectuals. His poetic works in general and his stories in particular offer a contemporary viewpoint to his readers of various intellectual, social and political aspects. His inquiries about the nature of life and happiness, the way to awareness and political justice, the functions of religion and state, his skepticism about the concept of nobility, and his appreciation to learning and knowledge, etc.: all these would generally form a reformation project, socially and culturally, where all these aspects are considered to be a result of a structural analysis of the text. $\square$ 


\section{يِّشَكى كي:}

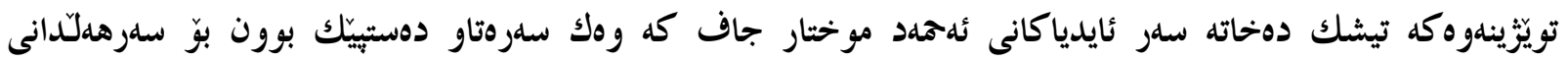

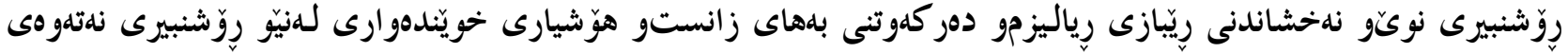

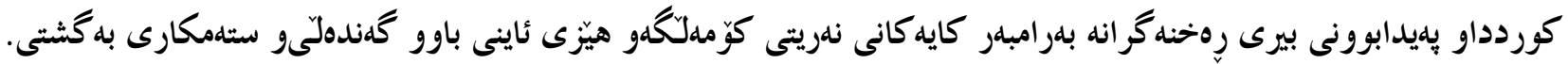

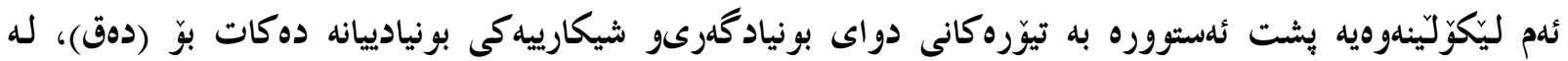

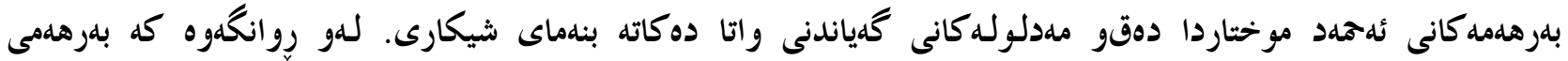

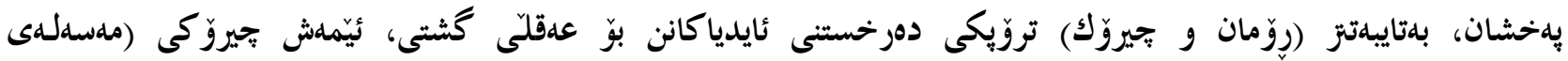

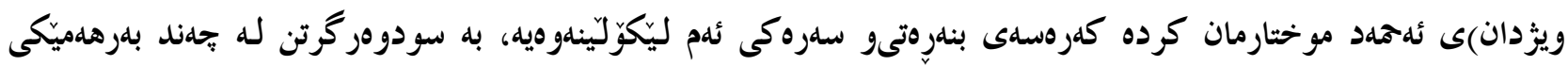
شيعريى.

\section{س}

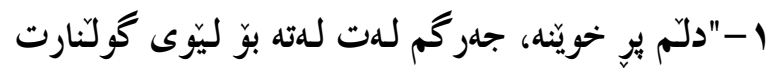

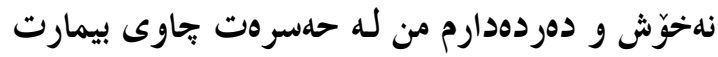

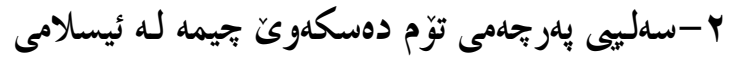

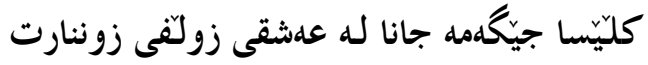
ب-وتى عاشت ئلبيّ بله كوشتنهات ملسروور يبى تجونكه لهناو عوششاقدا تهنها ئلتوّى قوربانى دلّدارت ع -شكا بازارى شههدو شهككهرو شيرينى يى قهنناد

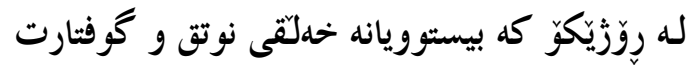

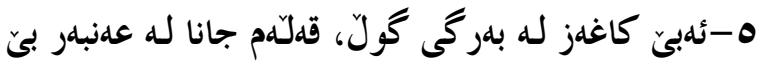
كه من مليلم هليه ئيّستا بنووسم وهسفى رِوخسارت

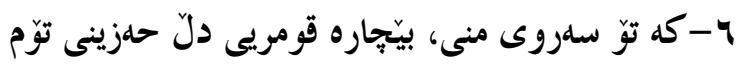

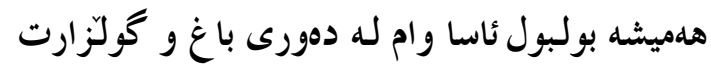

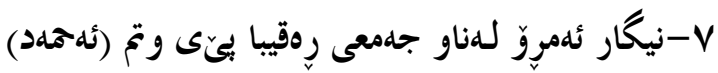

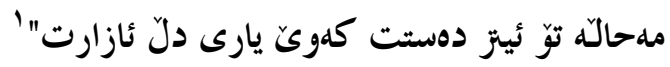

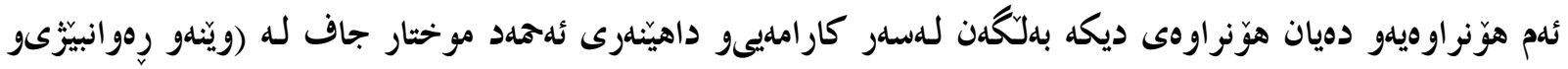

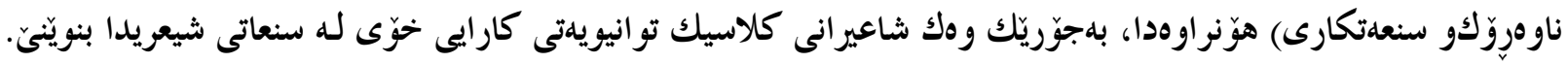
له روووى وهزيفهدان به شيعرو نوسينو بلهتنهوهى به واقيعلوه، ئهمهد موختار جاف به بيّشرِوى رِياليزم لله ئهدهبى

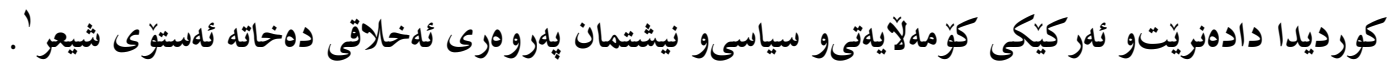




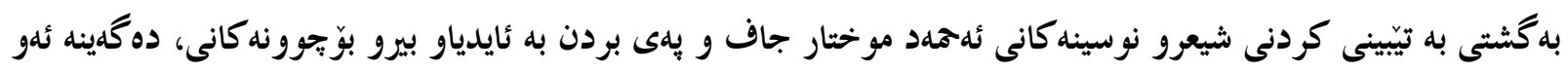

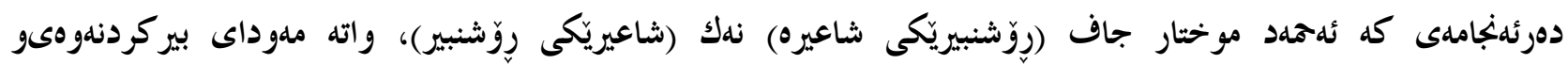

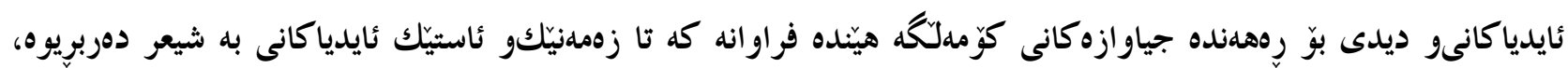

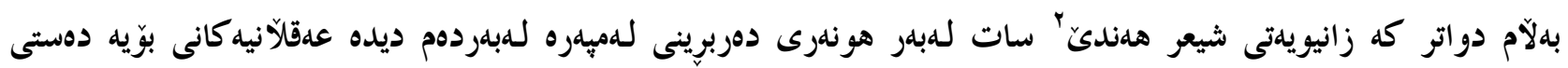

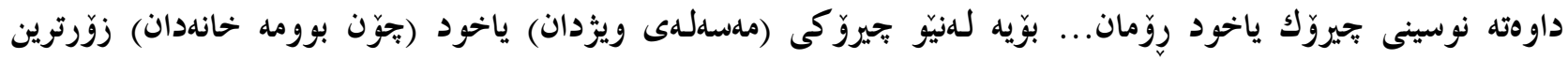

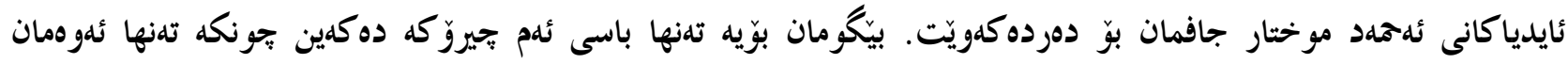

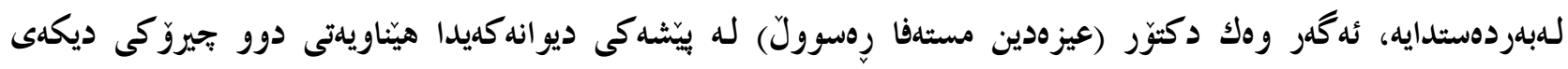

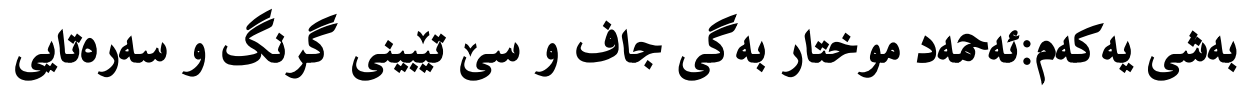

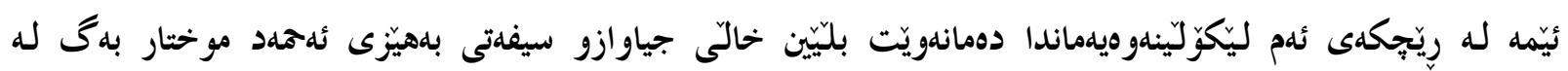

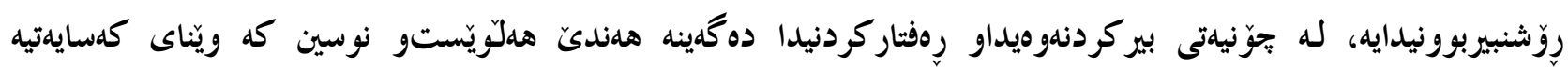
كموروكانى ميّزووومان ديّتهوه ياد:

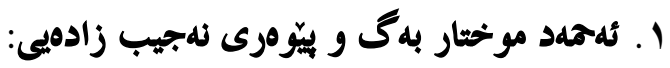

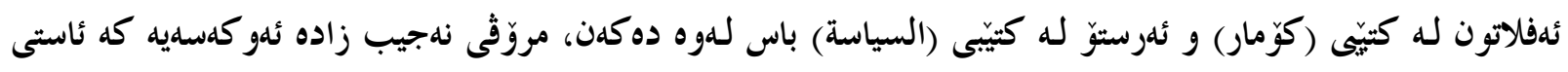

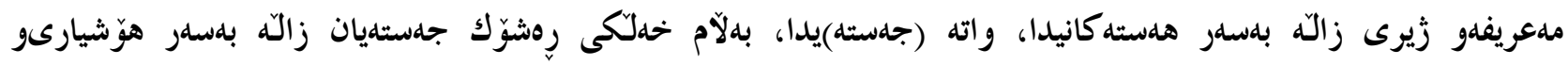

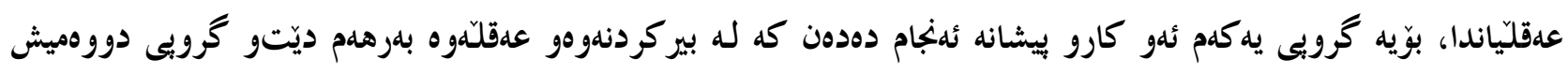

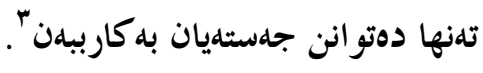

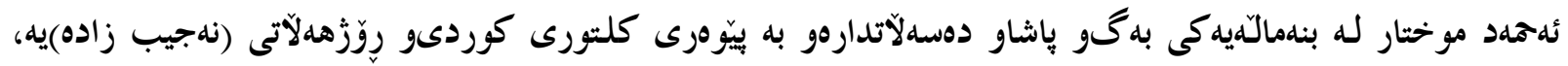

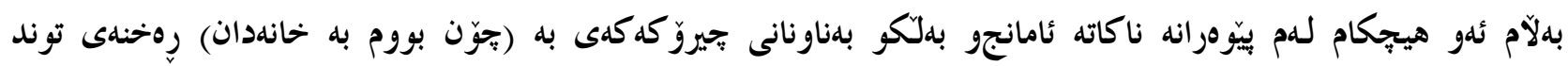

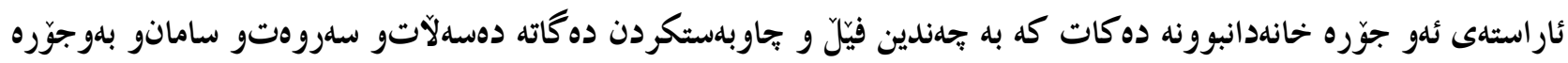

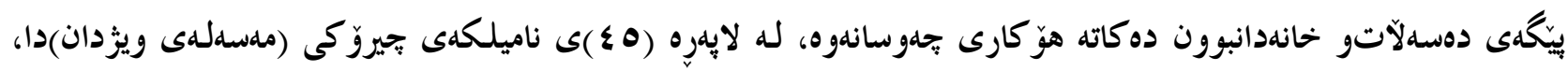

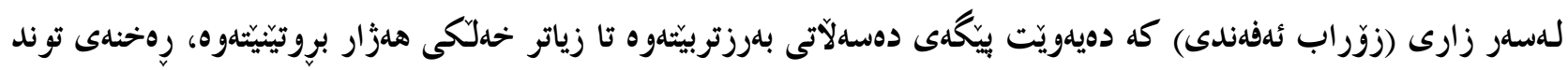

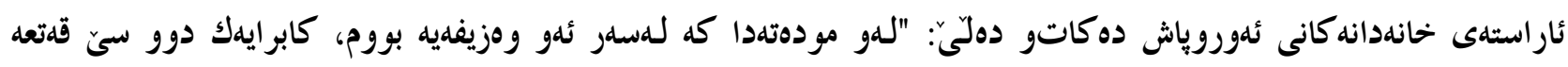

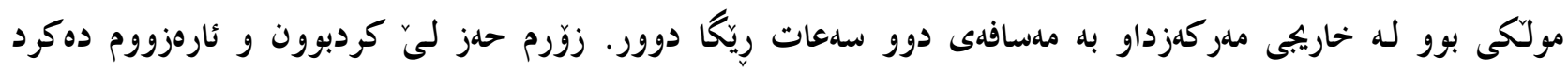

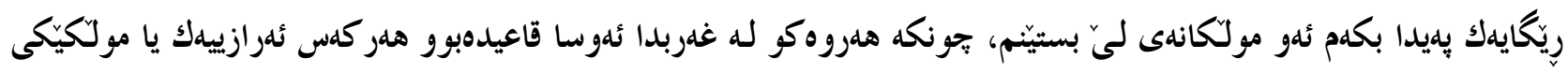

$$
\begin{aligned}
& \text { (1) بروانه: كتيبى (الو اقعية في الأدب الكردي) د.عز الدين مصطفى رسول، لجس ا -ه ب I. }
\end{aligned}
$$

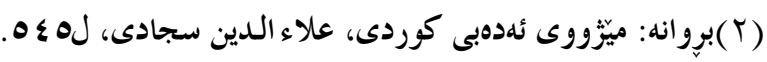

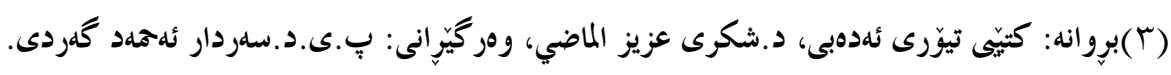




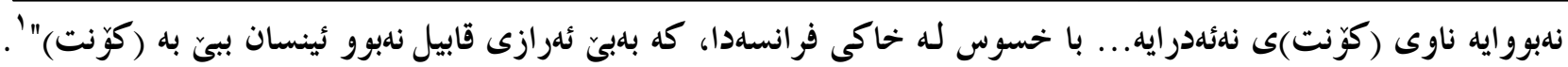

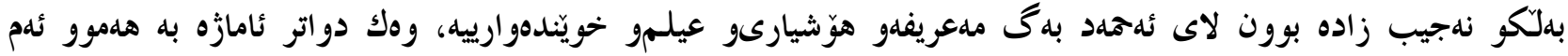
"حdمكانه ده كمين.

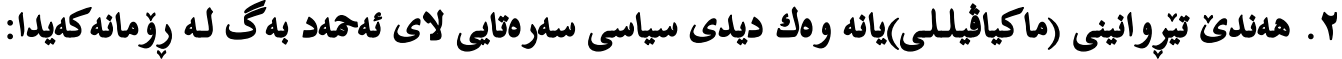

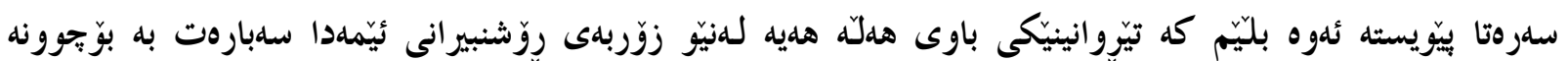

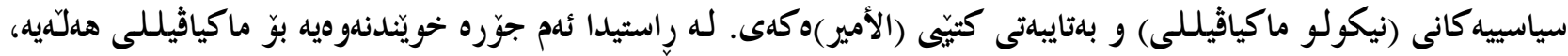
بلدلكو وهكو (فرنسيس بيكون) دهليّت: "ماكياقيللى بابهتى كهسهكان دهخاته رِوو بلهو جوَرو شيّوازهى كه هلن نهك وهك

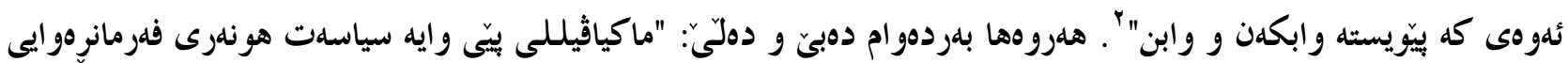

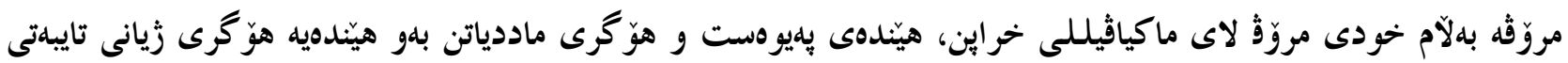

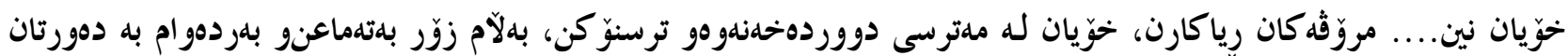

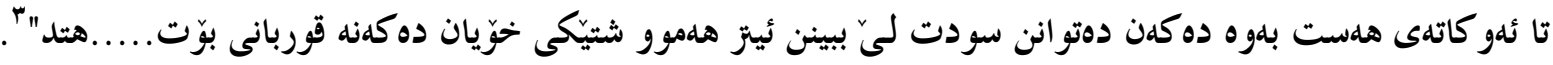

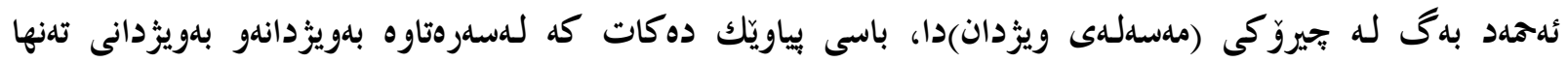

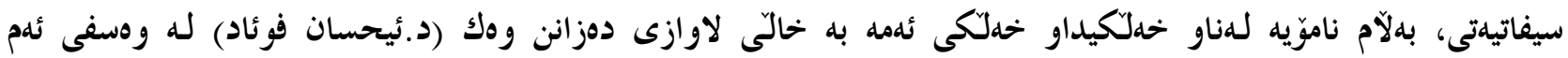

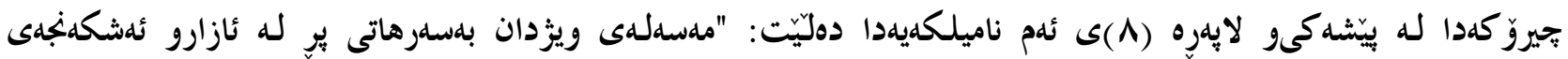

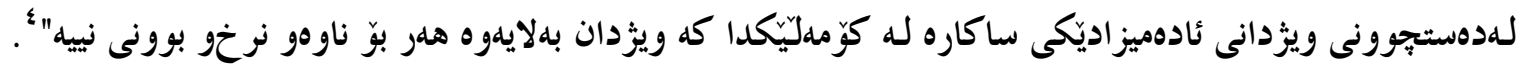

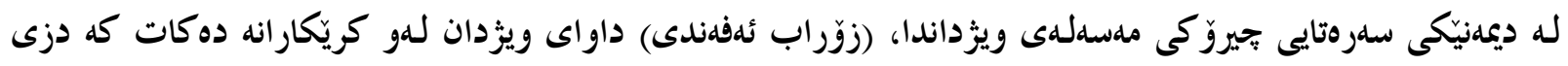

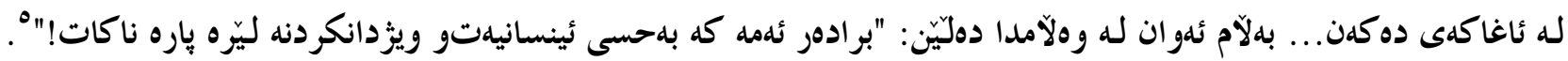

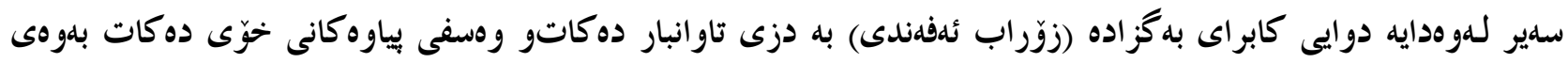

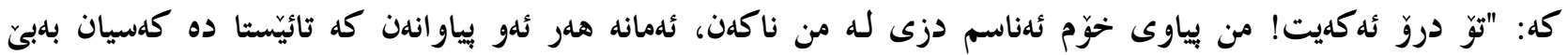
قهباحلت هلر للهبهر ئارهزووى من بوّيان كوشتووم و سهد كاروانيان بوّ رِووت كردوومهتهوهو ئهم مولّكانه كه من هلمه له

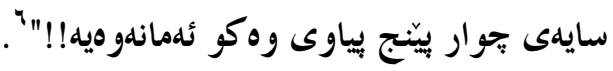

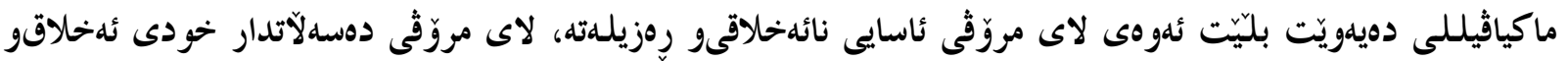

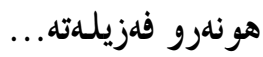

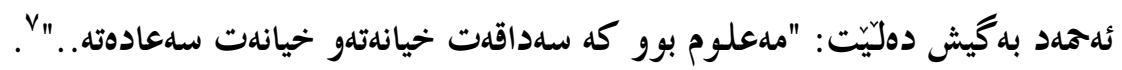

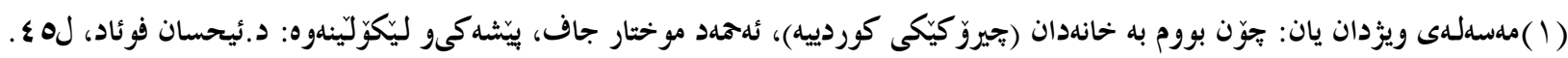

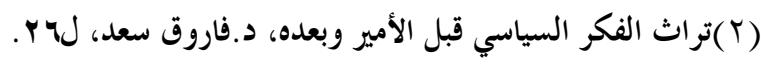

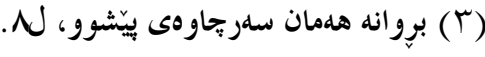
.N (0)مهسلدى ويزٔدان، لب ץ. (T ) ملسهلهى ويزدان، لع r.

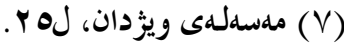




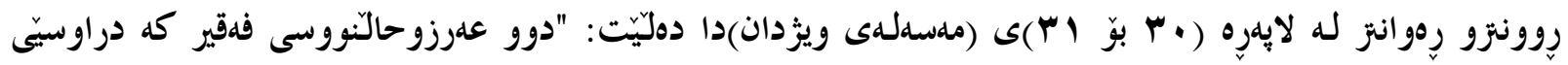
دوو كانم بوون و وهجهى مdعيشهتيان تهنها ئيستيدعا نووسين بوو، به ئهمى بلهلهديه مهنع كران! منيش هلرجهلند قهلبهن

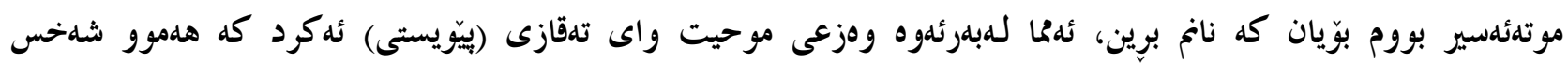

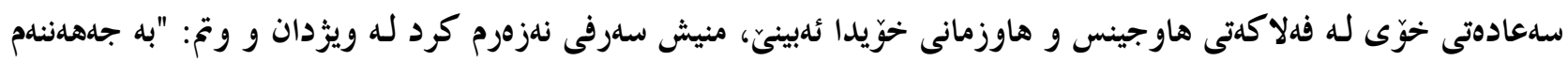

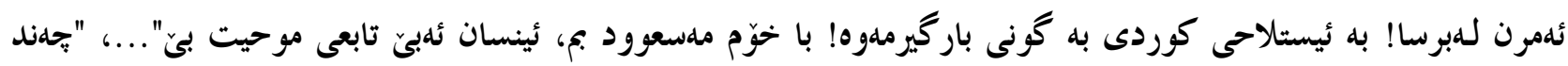

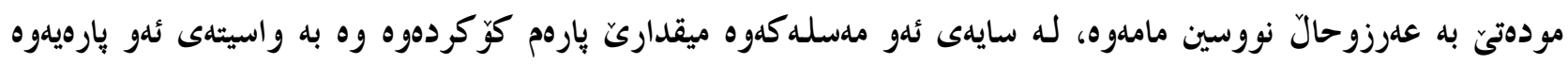

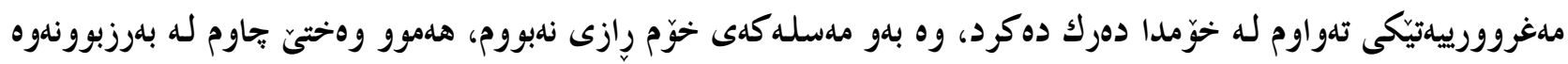

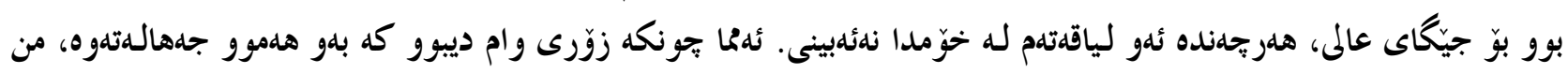

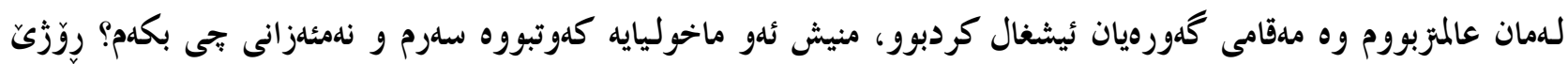

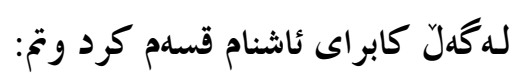

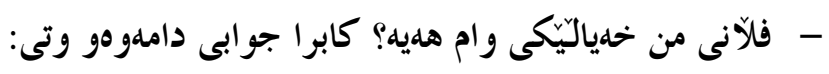

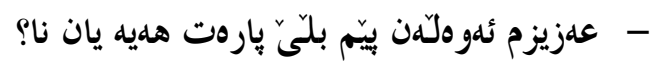
- ملبلمغغيّكى كافيم هليه.

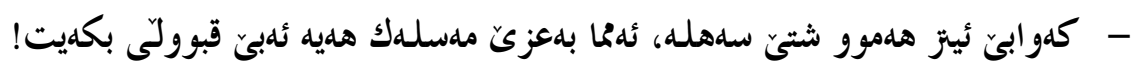

$$
\begin{aligned}
& \text { - وهو تجى؟ }
\end{aligned}
$$

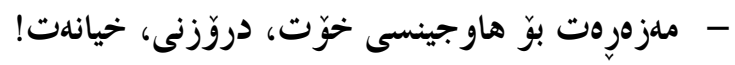

$$
\begin{aligned}
& \text { - } \\
& \text { ئاشناكهم جوابى دامهوه: }
\end{aligned}
$$

- ئهمانه للهم موحيتهدا وهكو شههادهتناملى مهكتهب وايه لله سائيرى ولّاتانا! هلتا وا نهبى ئوميّدى تهرهقيكردن بحّ

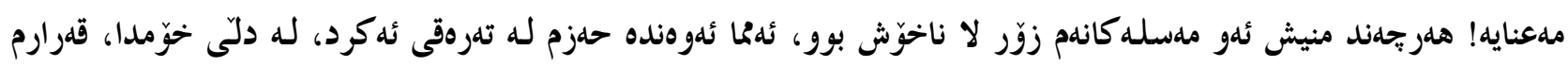

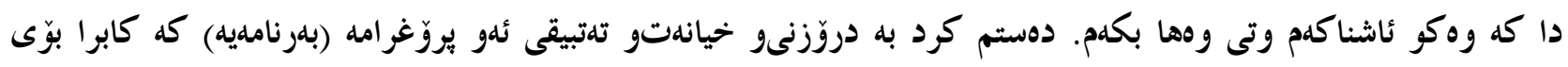

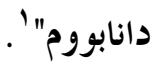

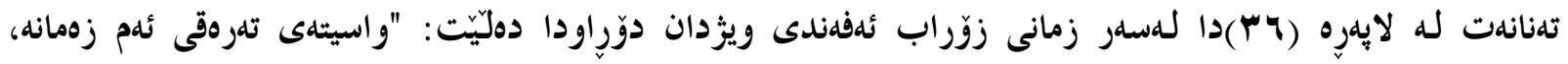
ناراستىو نهخويّندهوارىو ساحيّب يارهييه، من هلر سيانيانم هليه..." دواجار كه للهسهر دزى ده گيرى خوّى ده كاته وهتهنىو

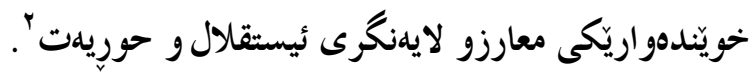




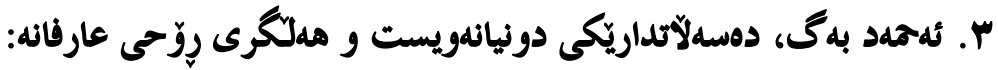

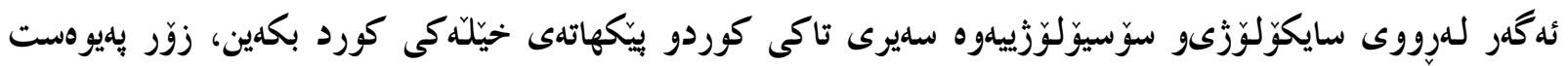

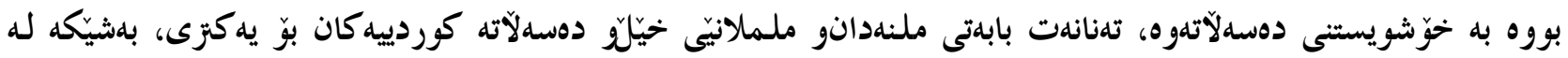

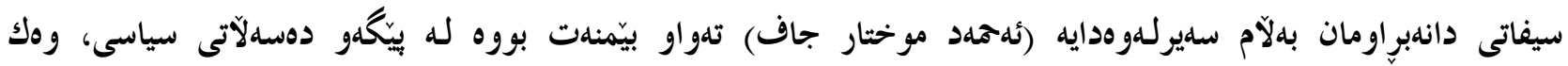
(د.عيز هدين مستهفا رهسوول) دهلّيّت: "له رِووى سروشتو بيزهوه تهماشاى رهفتنارى ئهحهد موختار دهكهين، دهبينين ئهم

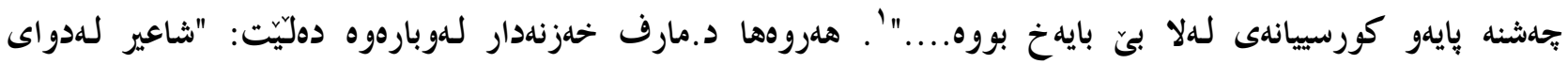

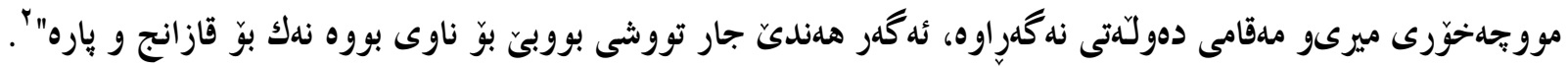

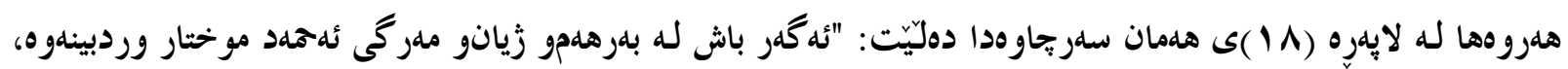

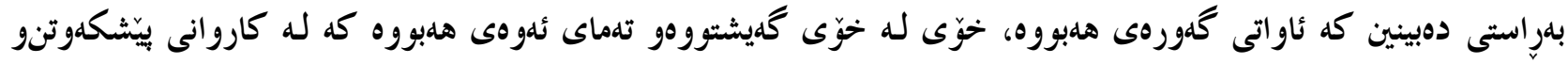

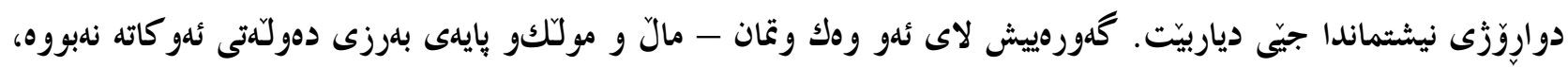

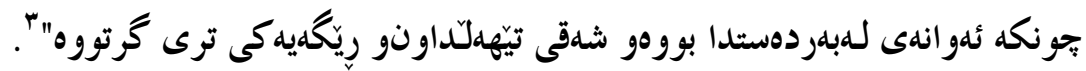

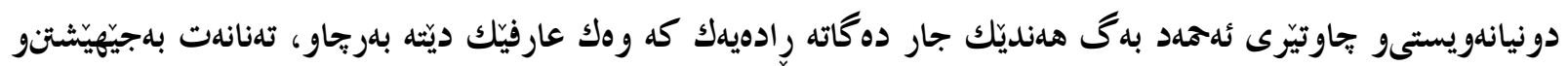

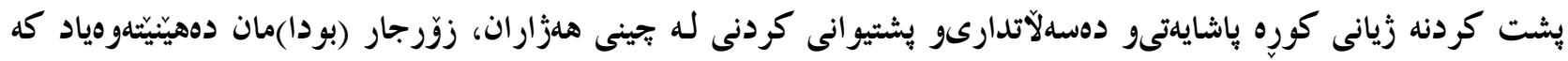

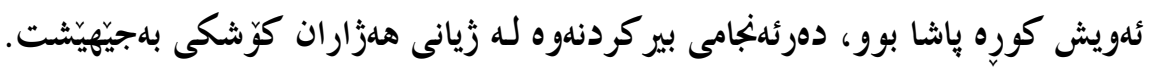

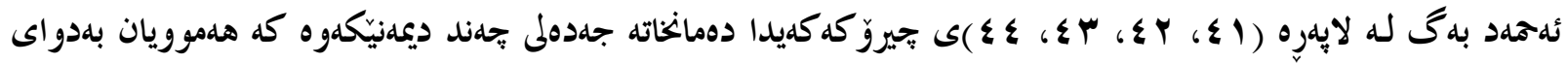

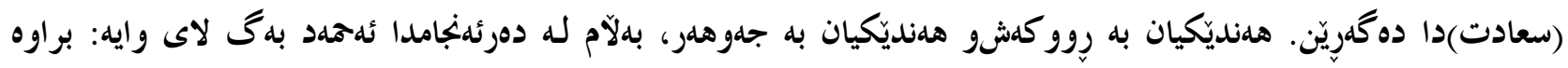

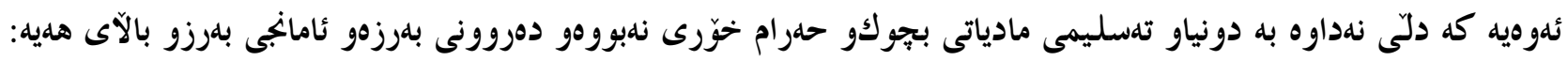

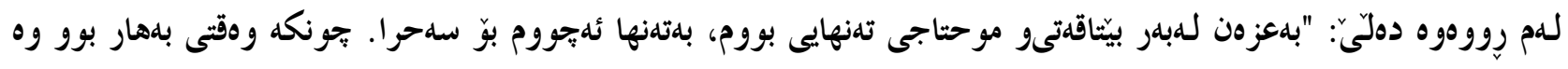
هلموو كهس ئيوّاران ئهجوو بوّ دهرهوه، تهسادوفى زوّر جلمعيلتم ئهكرد كه دانيشتوون دهسته دهسته. بلهزيّك عهرهقيان

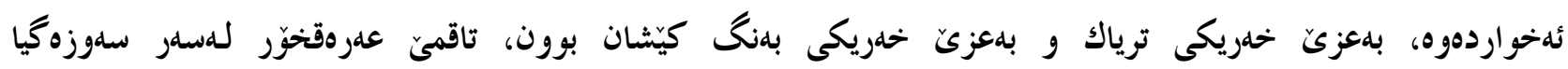

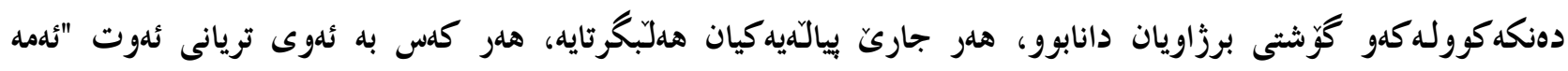

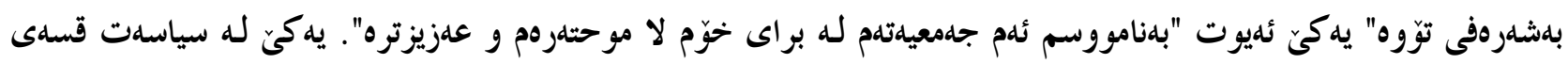

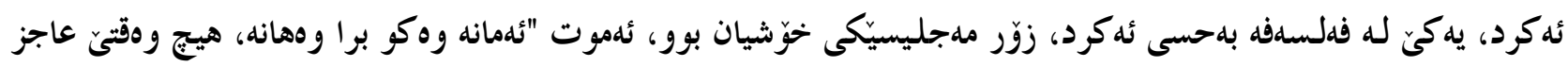
نابن، وهك له ئهملى ئلم علسره ناكهن".

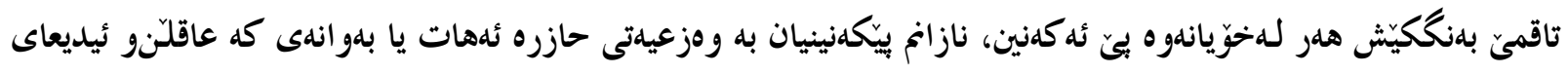

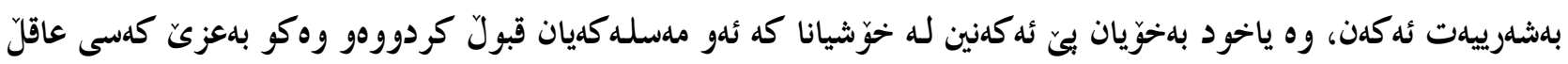

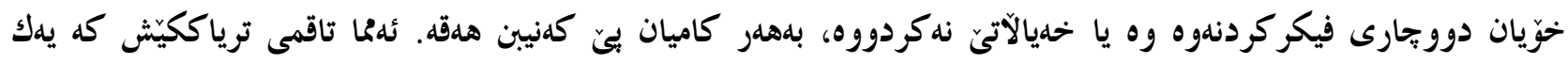

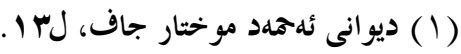

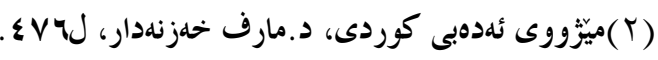

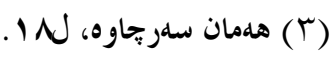




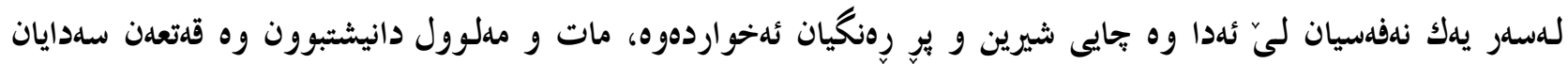

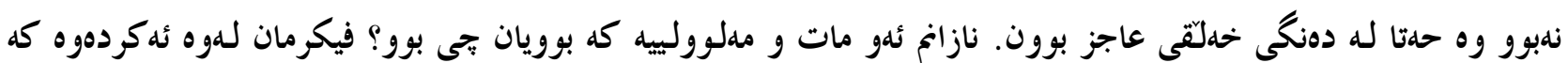

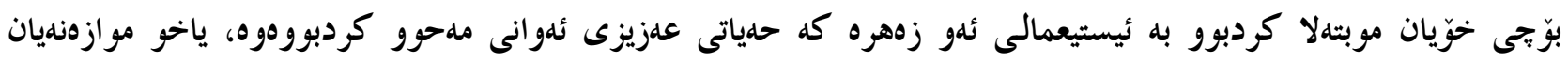

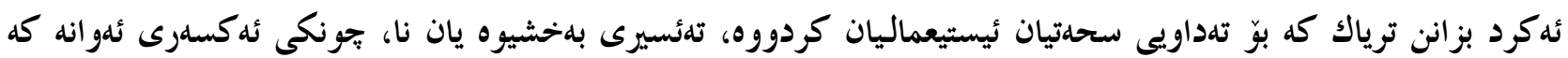
موبتهلا بوون به ئيستيعمالى ترياك بهبههانهى نهخوّشييهوهيه، كه له ياشاندا موبتهلا بوونو له ميعادى خوّيدا ئيستيعماليان

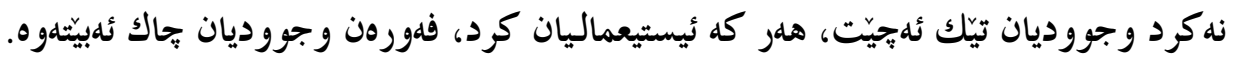

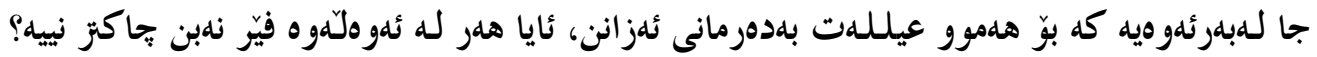

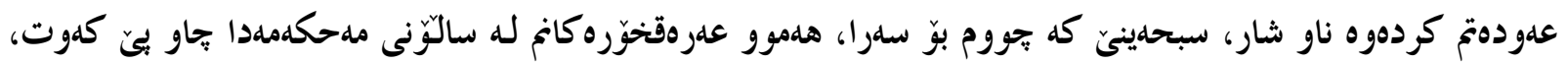

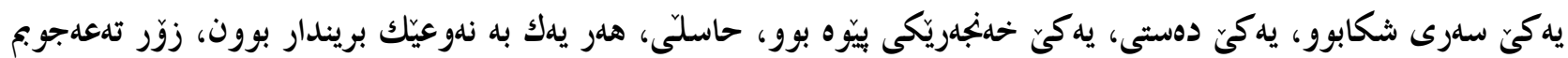

لله فهر اشى مdحكهمهم برسى:

-

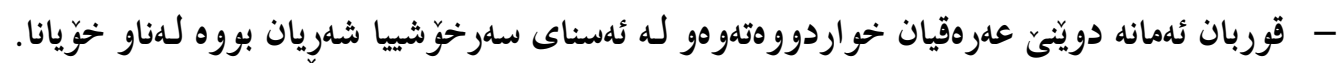

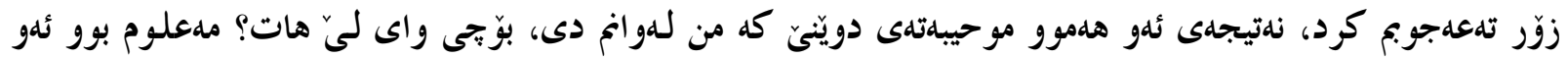

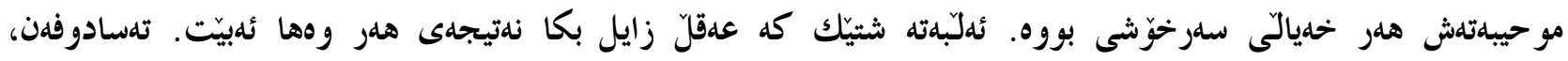

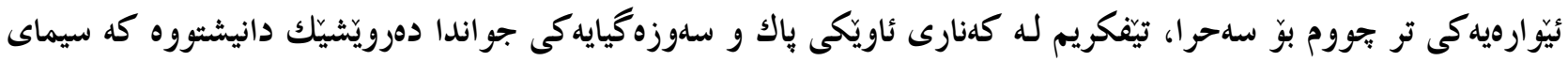

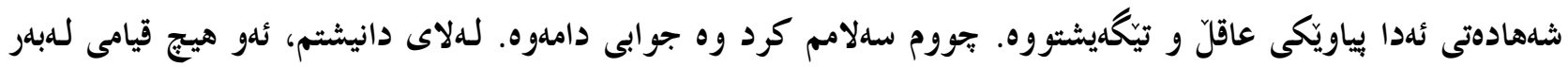

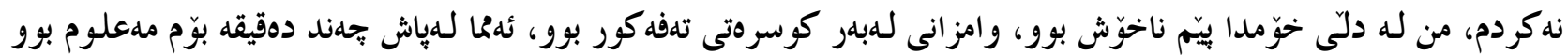

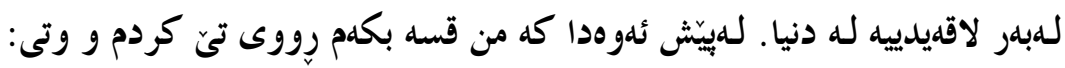

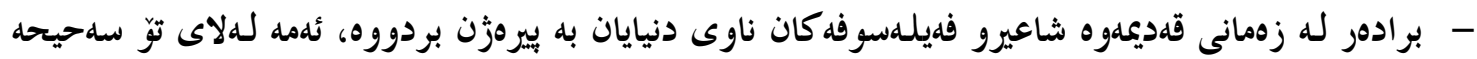

يان نه؟

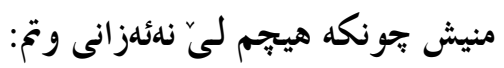
- تجيت علهرز بكهم؟ -

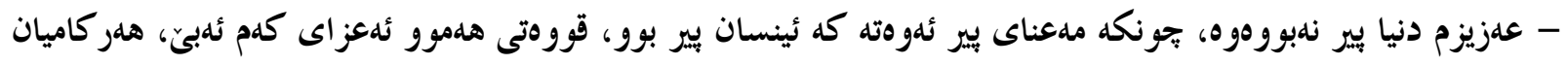

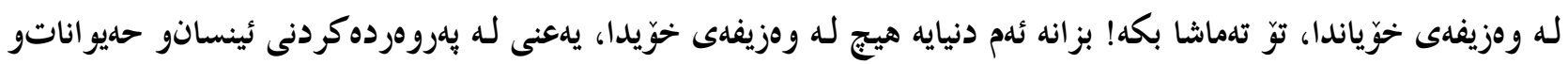
نهباتاتدا كهمى كردووه؟ لاكين ئهوهنده هdيه، خوّمان بير ئلبين، له كار ئهكهوين و ئلمرين قهباحلت ئهخلينه سهر دنيا.

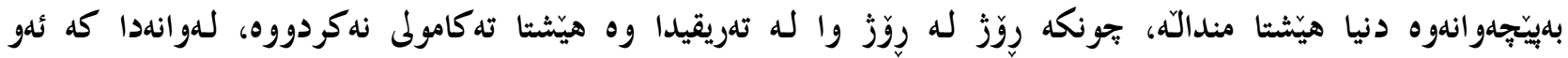

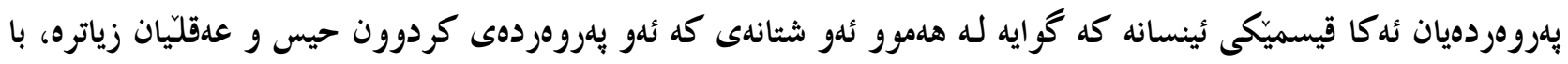

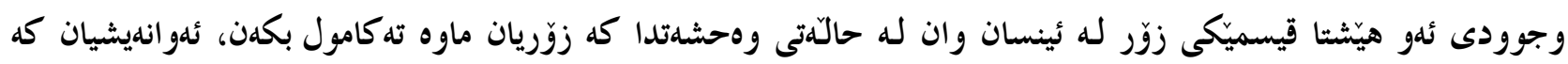

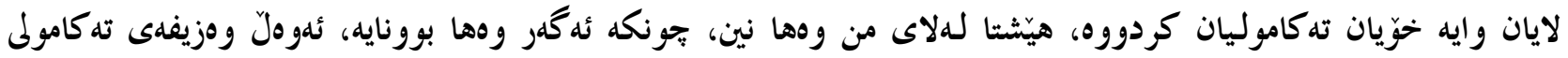




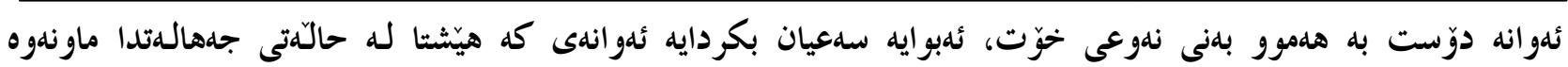

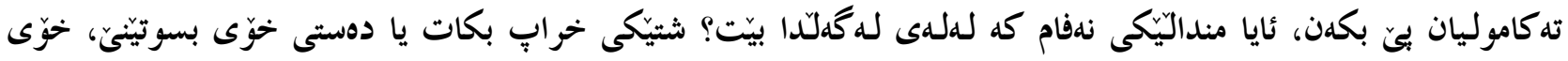

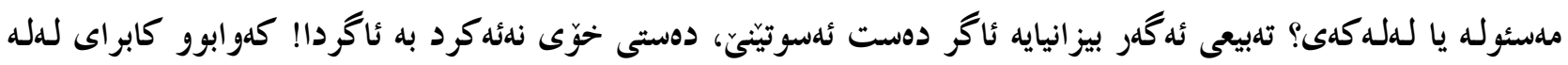

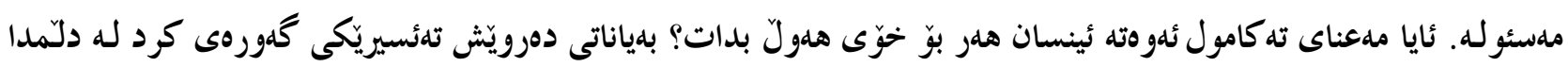

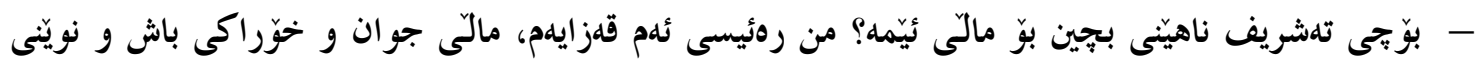

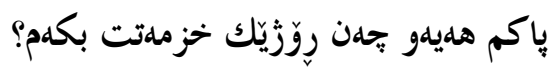

جوابى داملوه وتى:

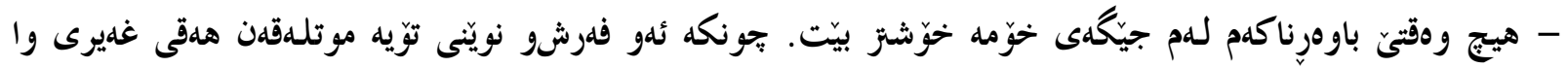

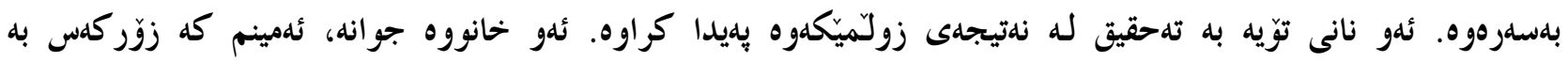

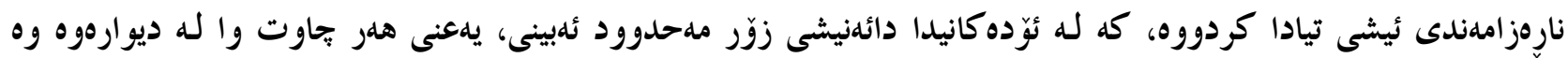

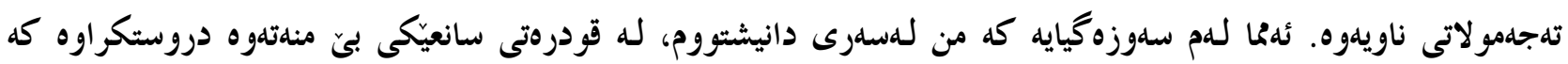

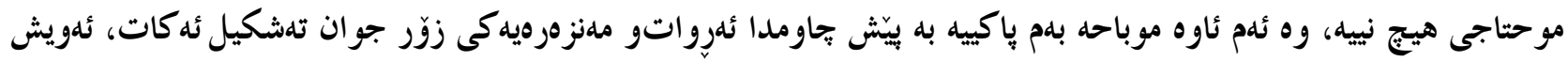

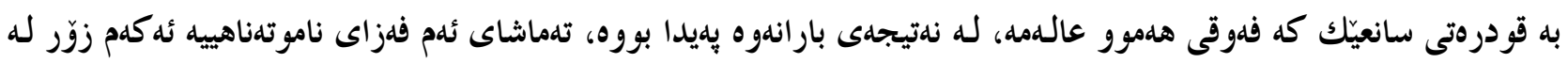

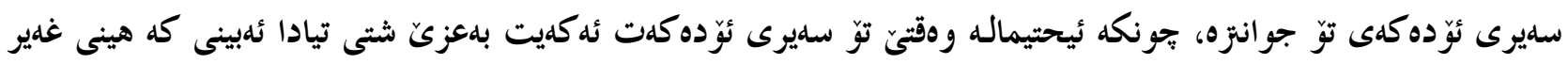

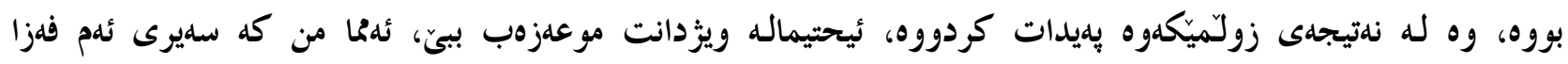

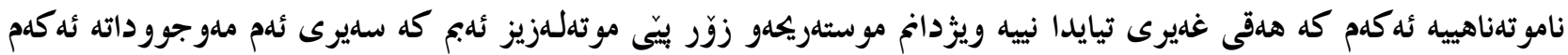

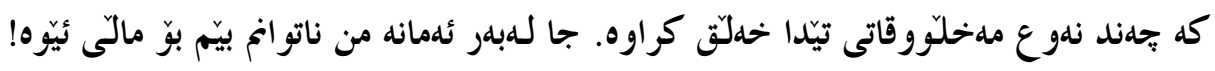

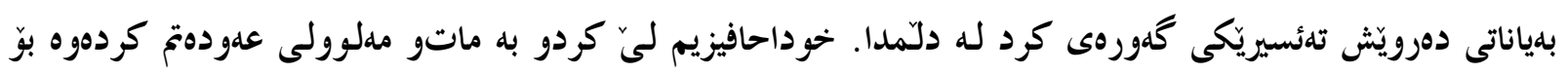

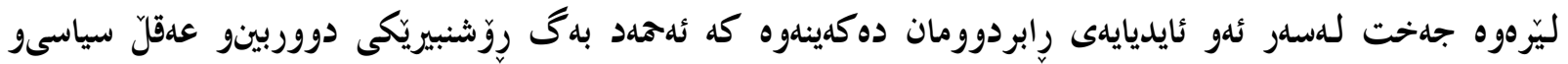

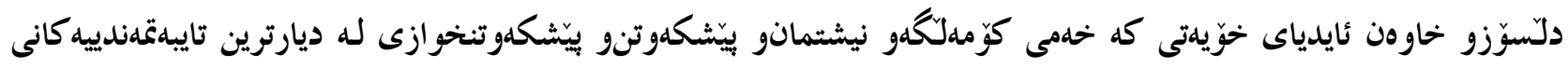
ئهم رِّشنبيره شاعيره بوون. 


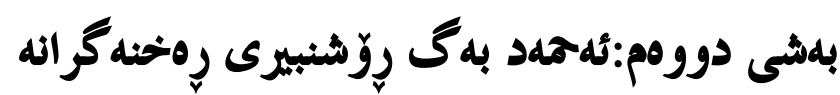

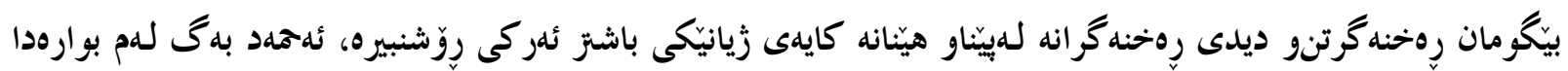

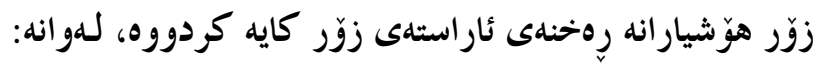

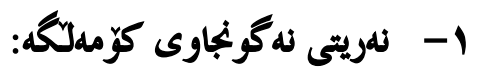

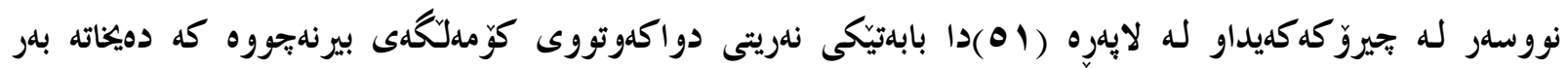

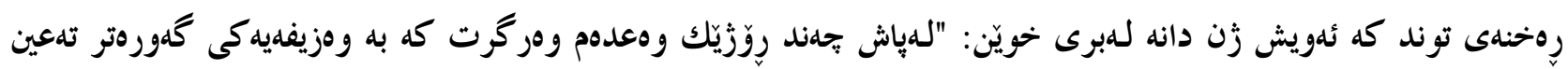

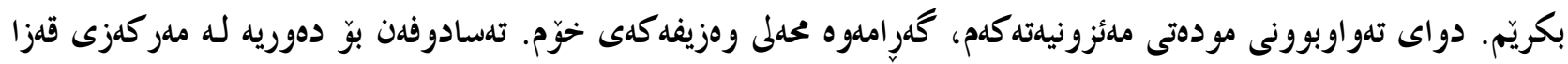

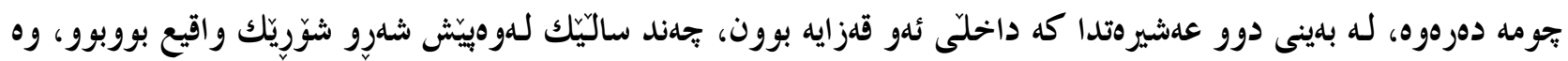

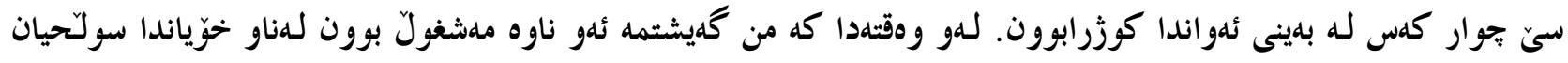

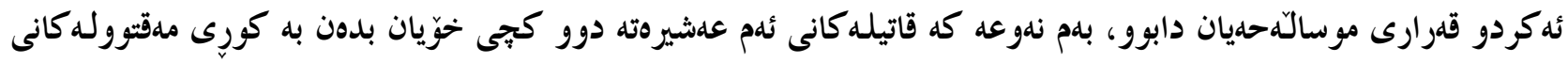

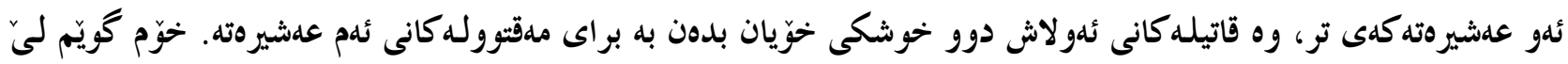

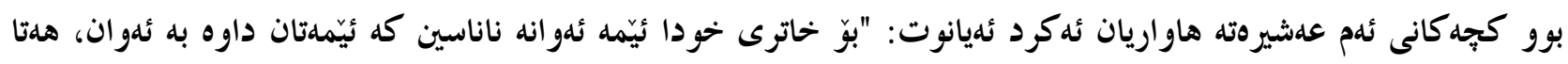

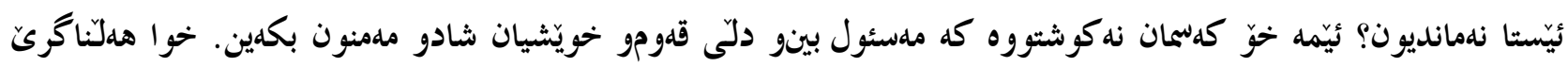

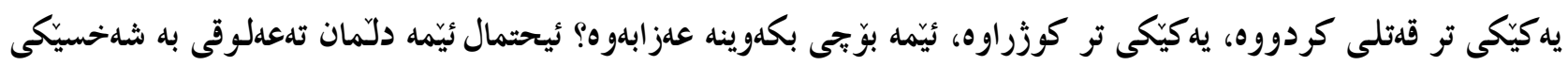

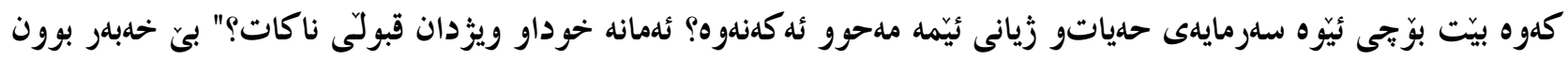

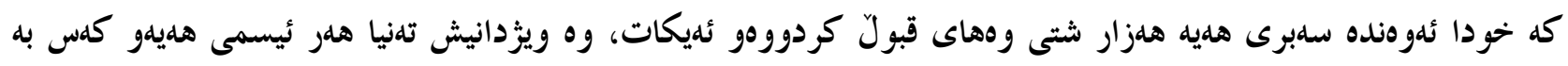

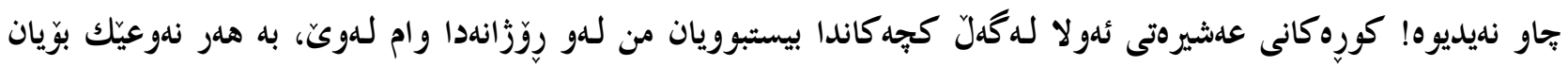

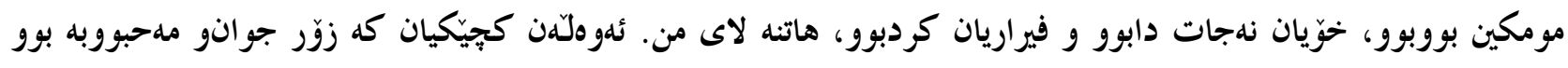

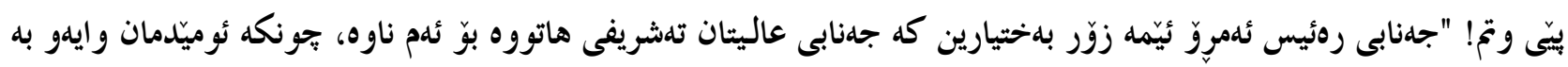

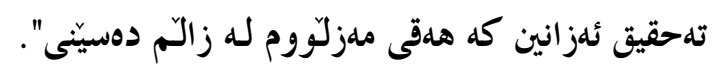

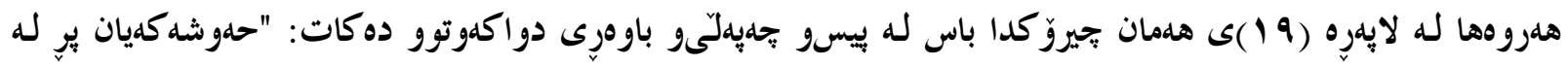

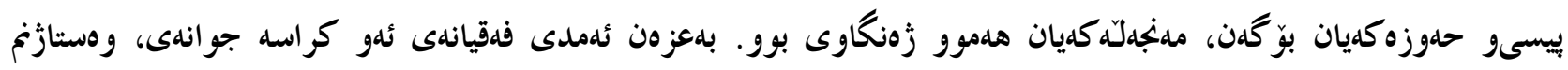

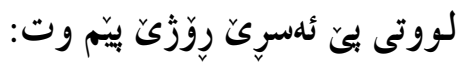

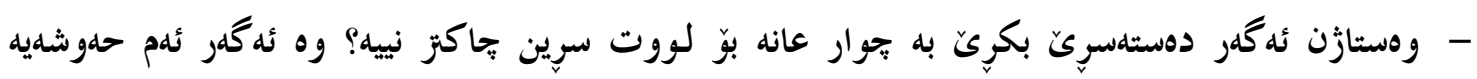

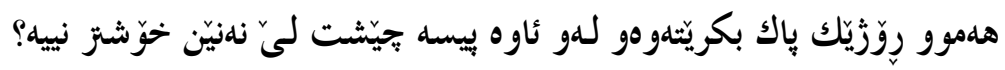

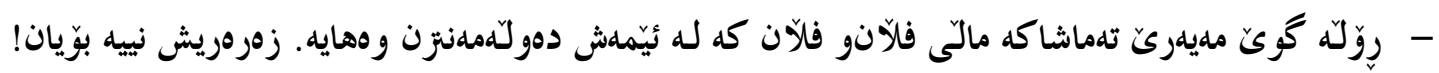

$$
\text { - }
$$

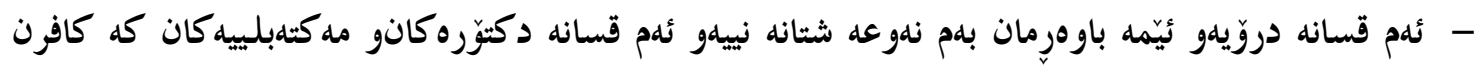

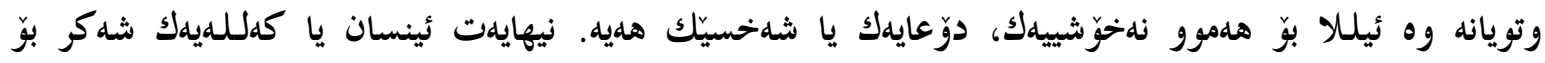




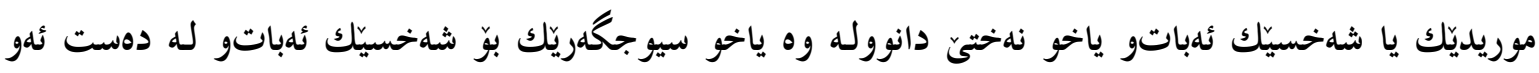

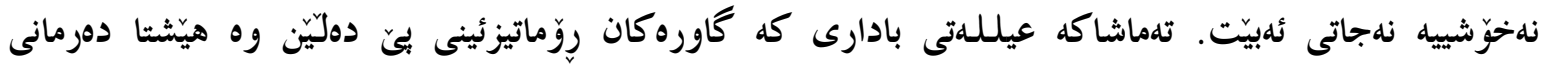

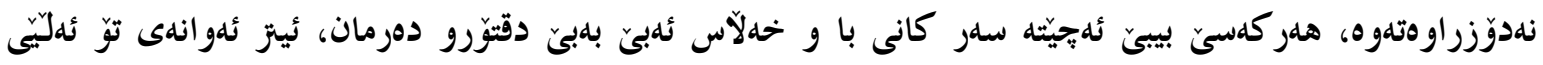

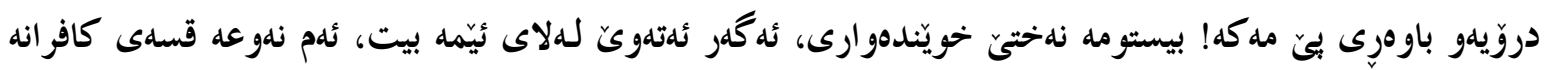

مه كه".

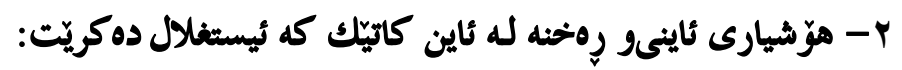

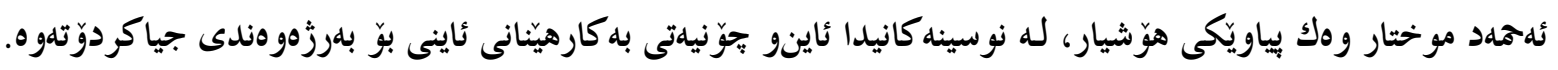

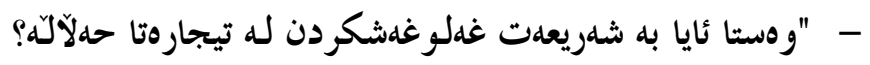

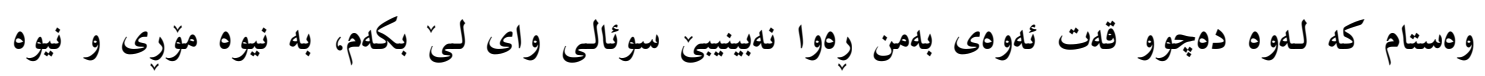
تلعهجوبيّكهوه سليرى كردم و ئلمجا فهرمووى:

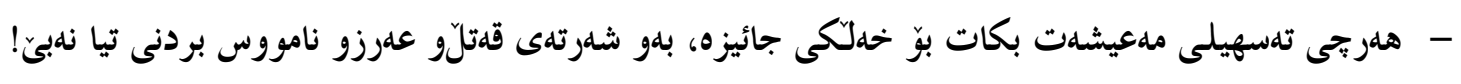
- - هلتيو للهمه زياتر قسه مه كه!" . هلورو

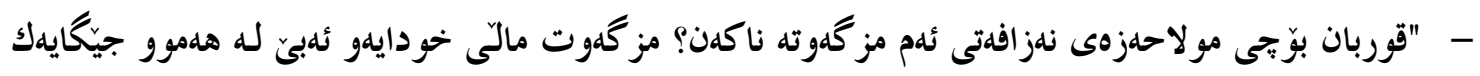

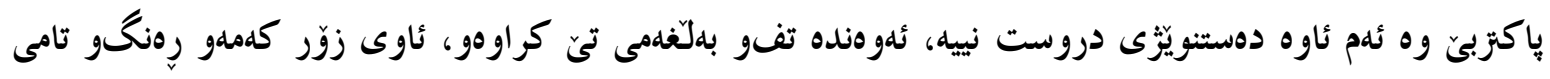

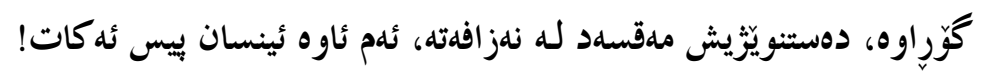
ماموَستا جوابيّكى زوَر ملعقورولى دامهوره:

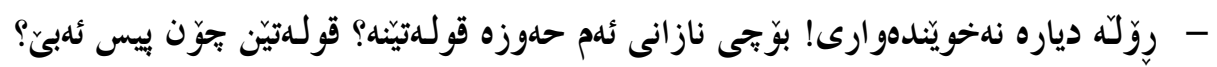
كهو اي فهرموو سكووتم كرد.

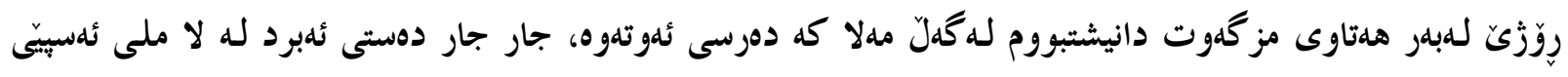

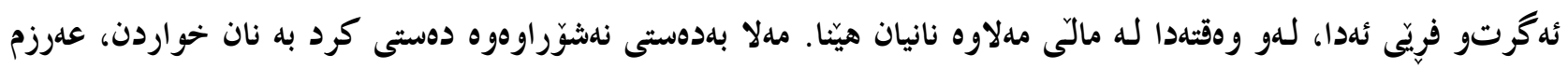

$$
\begin{aligned}
& \text { - قوربان بوَّى دهستت نهشوَرد؟؟ }
\end{aligned}
$$

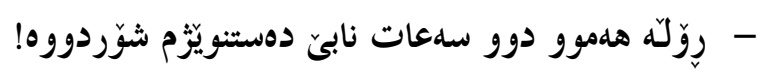

$$
\begin{aligned}
& \text { - }
\end{aligned}
$$

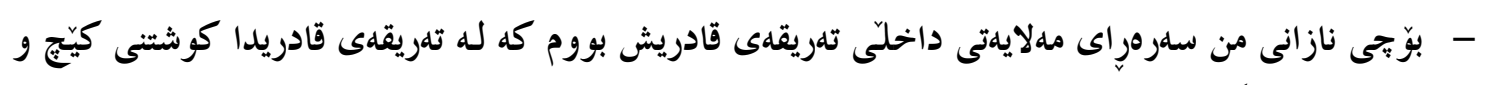

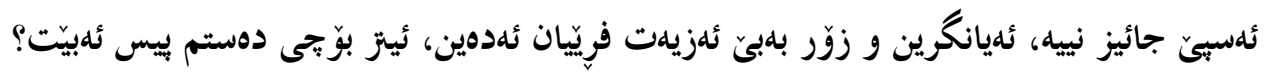


هdقيقهت تلقديرى مهسلهكى مهلام كرد كه ئهوهنده تهرهفدارى موحافهزى زيورحه (كيانلهبلر) وه هيج ئارهزووى زهحمتى زيروح ناكات.

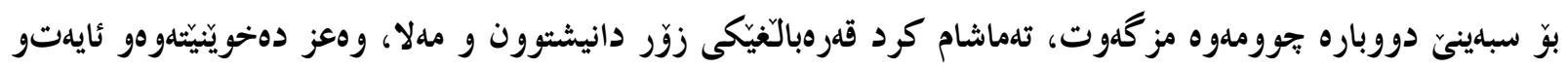

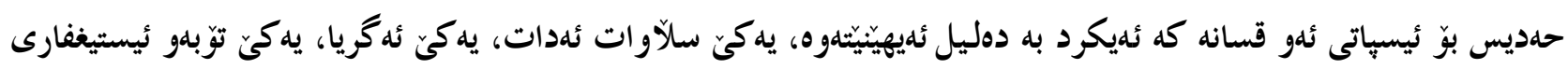

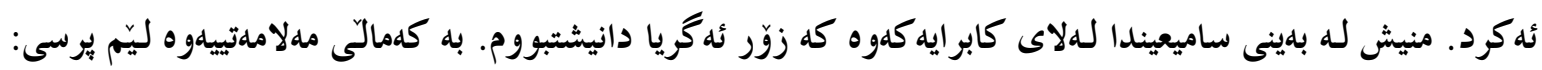

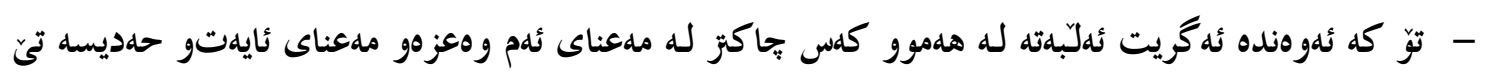
ئه كليت.

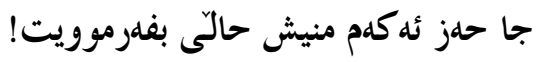

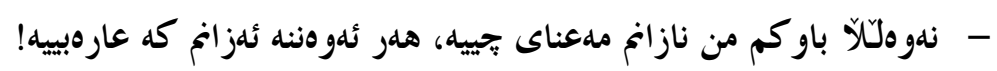

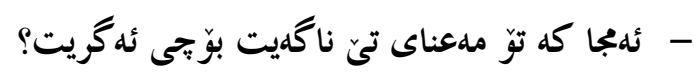
- - بيستوومه هلربتى به عارهبى بيّت بلهحسى قهبرو قيامهته!

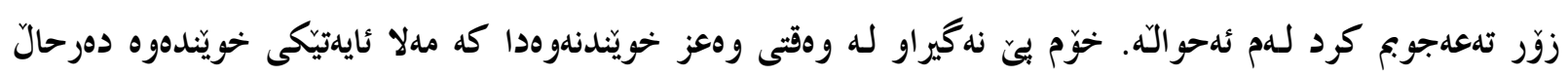
علرزم كرد: - قوربان جوزنكه من زمانم عارهبى نييهو مهعناى نازانم، ئهةهر مهعناى ئلو ئايدته بهكوردى بفهرموون زوّر مdمنوون ثهبم!

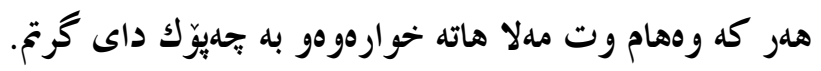
وتى: كافر بوويت، قسه مه كه!

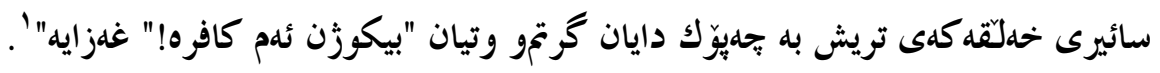

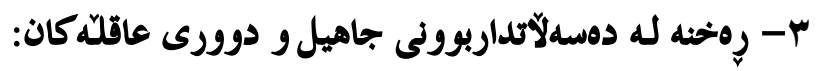
كيّشهى كَهورهى نيشتمان ئهسيرى ديّوى جلهمله.

1 - 1 مه كهن مdنعم كه وهك مdجنوون خهريكى هاتو بحوّى كيّوم

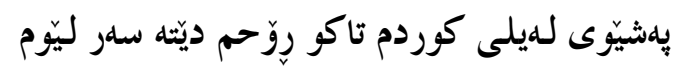

ץ- Yوهتلن فهرمووى به خحهندهى نازهوه هلرووك يهرى و امه

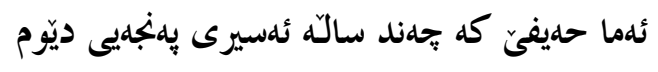

ب-هdميسان بيّى وتم ئهوسا مdكانى شهخسى عاقل بووم

فهقهت بحيبكهم ئلمه بحهند موددهته بيّ ساحيّب و خيّوم

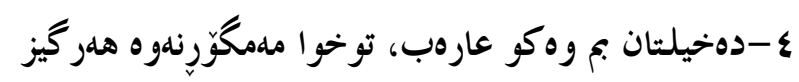




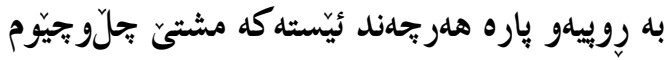

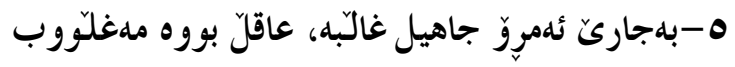

$$
\begin{aligned}
& \text { رهوفيقان سا نيشانم دهن قوريَّ تا بيّمو بييِّوم }
\end{aligned}
$$

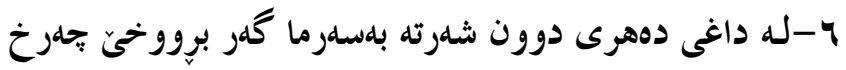

$$
\begin{aligned}
& \text { كُلَّ نامهردم ئهر شانم للهبهر ئهو باره ببزيّوم } \\
& \text { V له عهرسهى شيعردا، (ئهحمد) عهجايب شههسواريكه }
\end{aligned}
$$

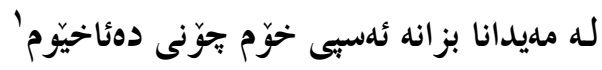

$$
\begin{aligned}
& \text { ع- روخنه له ملحسوبيلت و ملنسوبيهت: }
\end{aligned}
$$

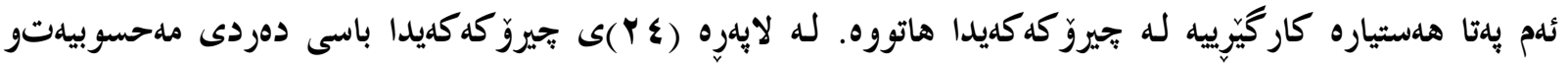

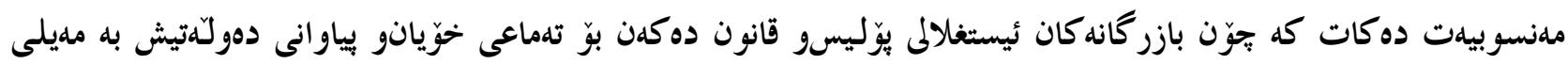

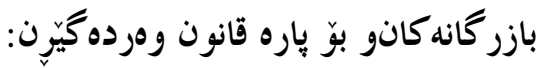

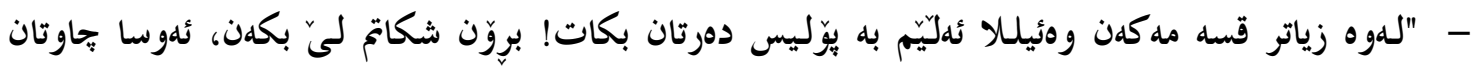

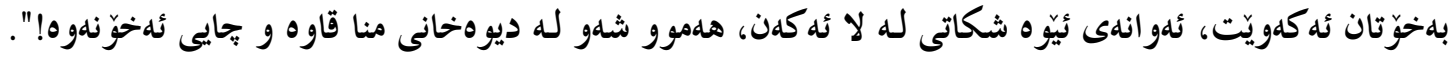

$$
\text { 0 - ئهمد به و و روخنه له سيستمى ئيدارى: }
$$

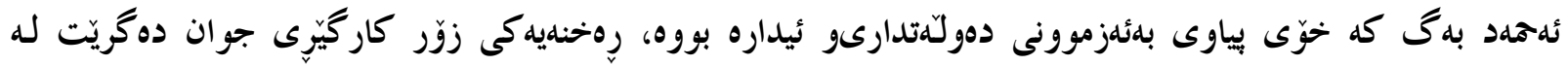

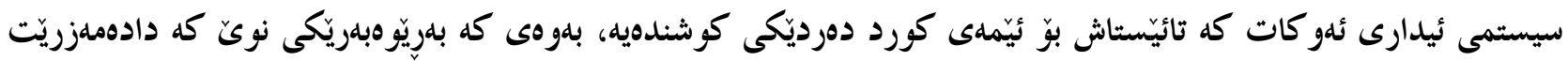

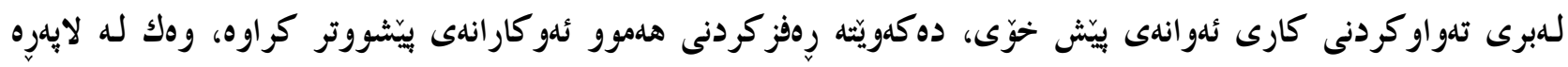

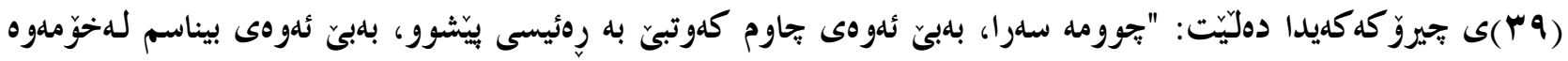

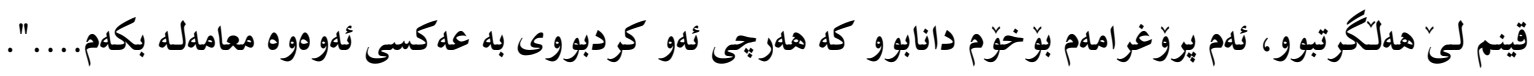

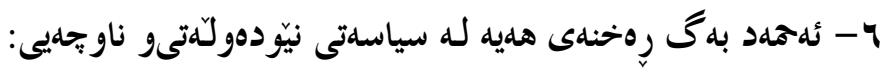

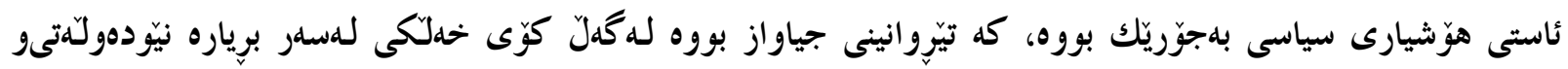

$$
\begin{aligned}
& \text { צ-حالَّى كورد ئيّستا له بلهينى تورك و وئيّران و (............. } \\
& \text { بيّجِوه تلهيره كلهوتووهته داوى مندالآنهوه } \\
& \text { V }
\end{aligned}
$$

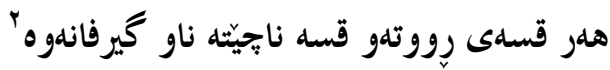




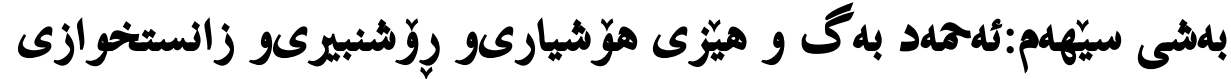

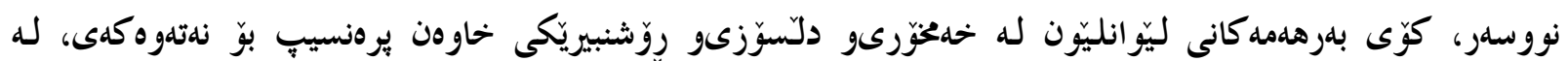

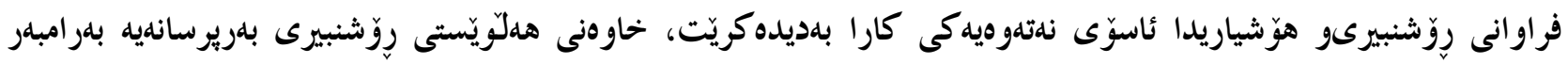

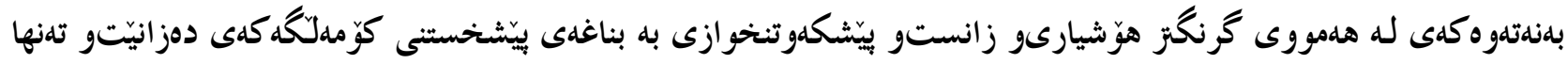
نهزانينو دو اكموتن به دوزمنىو للهميهرى سهرهكى دهزانيّت' .

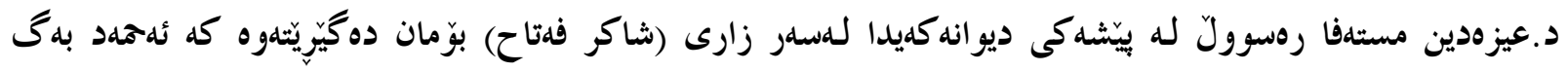

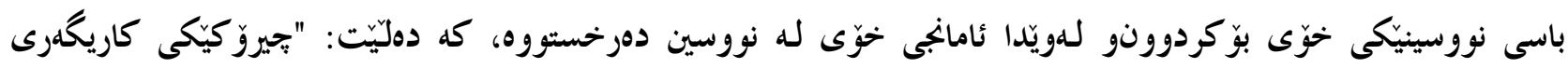

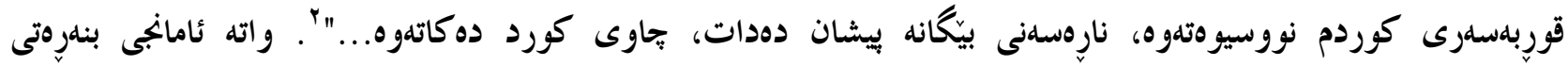
جاو كراوهيى كورده...

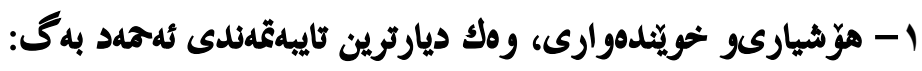

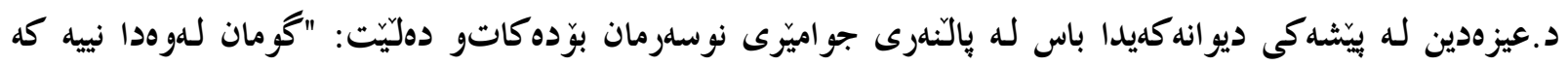

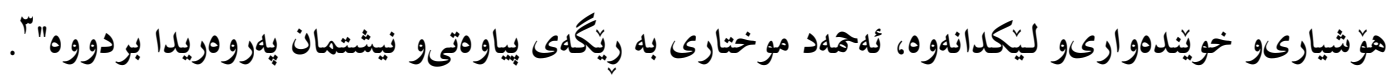

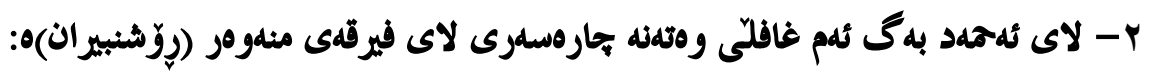

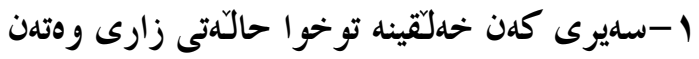

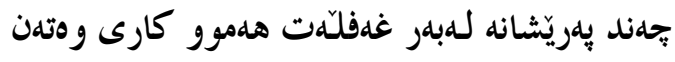

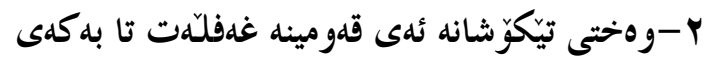

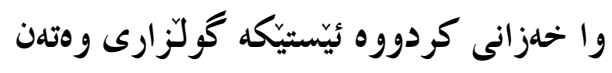

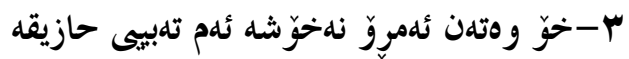
تحى ئلبىّ بيكا موداوا قهلبى بيمارى ووتلهن ع - كورانيّ خهلّقينه للهكويّن فيرقهى مونهووهر تينهتان جونكه ئهو فيرقه ئهزانن دهردو ئازارى وهتهن

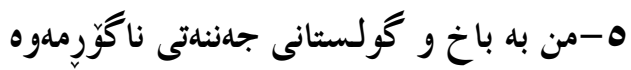

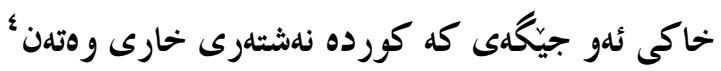

(1) ميّزووى ويَّزهى كوردى - صديق بوره كميى - بهركى دووهم، لـ 97.

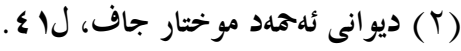

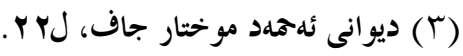

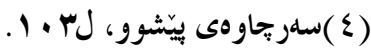


ب- لاى ثلحهد بهى مه كثلب تلداويه، عيلم و عيدفان سيلاحه: هdلّ بكهن ....... كوردى مdقسهدم تالآن نييه ૧اره تهحسيل كردنو روووت كردنى كاروان نييه غليرى مهكتلب بوّ تهداويى ئيّمه هيج دهرمان نييه هيج سيلاح جاتر لله عيلمرو سنعهتو عيرفان نييه

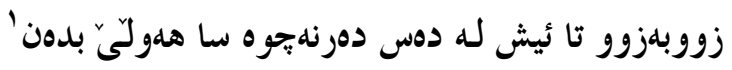

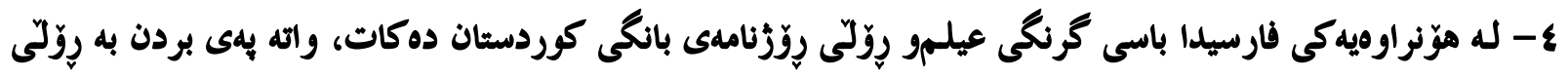

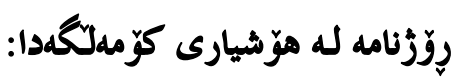

$$
\begin{aligned}
& 1 \text {-صبح بون خورشيد رخشان سر بزد أز كوهسار } \\
& \text { (بانگ كردستان) ما يرتو فشان شد اشكار }
\end{aligned}
$$

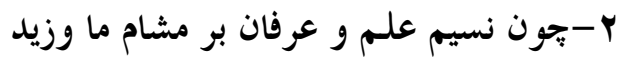

$$
\begin{aligned}
& \text { خواب ير شور جهالت كرد أز سرها فرار } \\
& \text { ب-گر بجشم عقل ما دقت نماييم اين زمان } \\
& \text { قوم كرد أز لطف حق هستند جمله بختيار } \\
& \text { ع - كور گثثته جشم حاسد، بختشان بزّمرده شد } \\
& \text { أز ترقى و تعالى همين قوم كبار }
\end{aligned}
$$

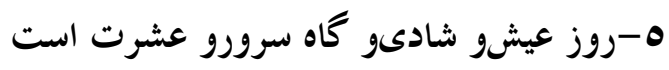

$$
\begin{aligned}
& \text { لايق است گر جان خود سازم بدين مزده نثار } \\
& \text { צ-هر كسى اهمال ورزد بـى گمان در وقت خود بد بد }
\end{aligned}
$$

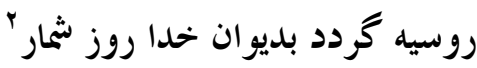

\section{๑- ترسى ستdمكار له مdعريفه:}

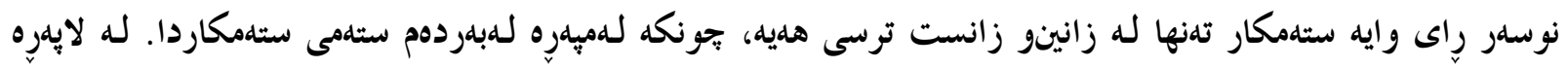

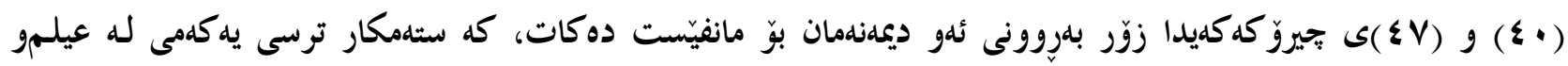

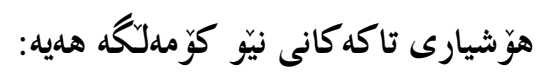

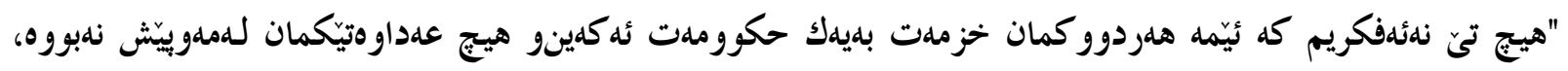

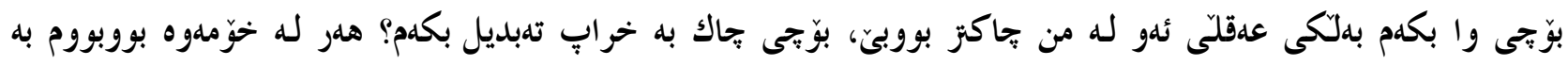




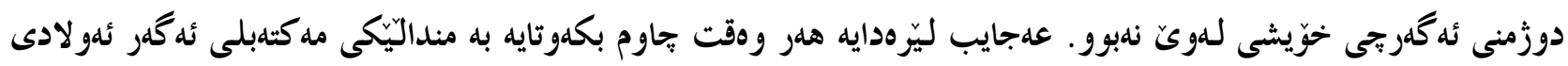

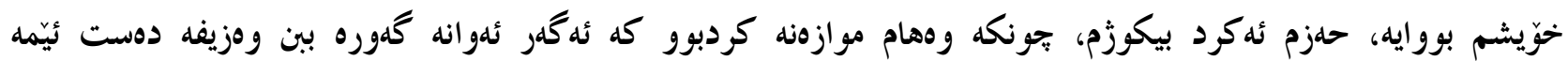

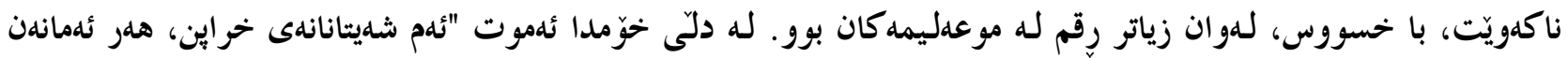

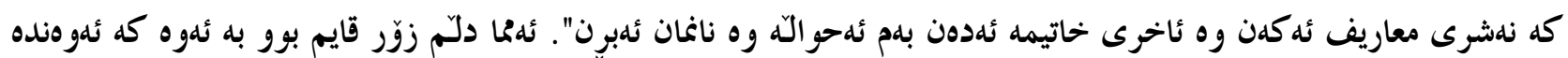

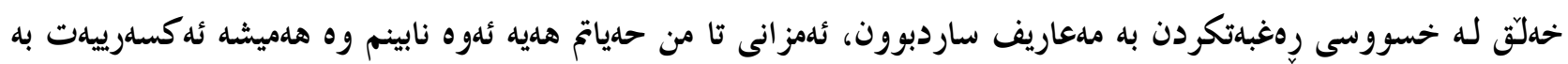

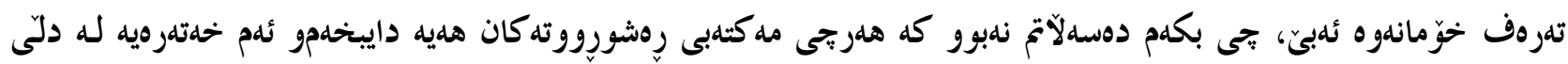

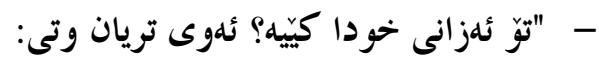

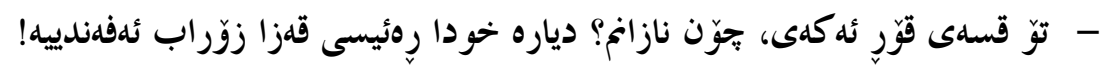

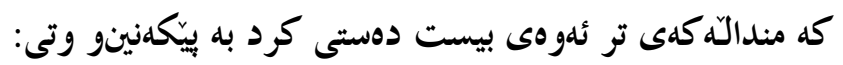

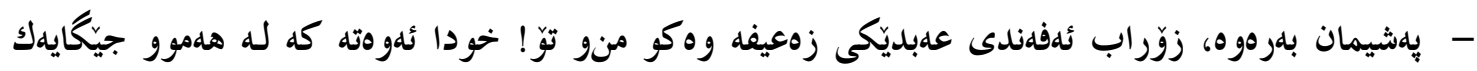
حازرهو ئلم دنيايهى دروست كردووه وه هلميشه باقييه. مندالّه كهى تر وتى:

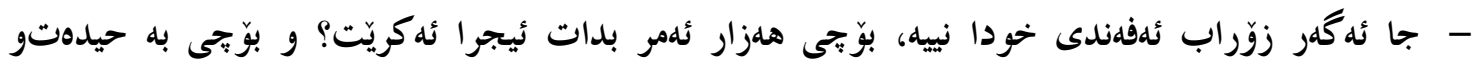

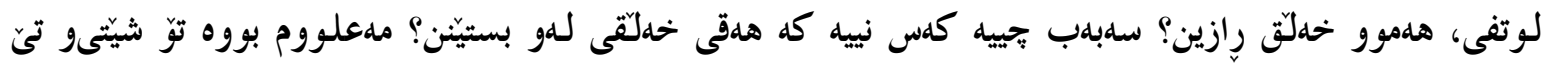

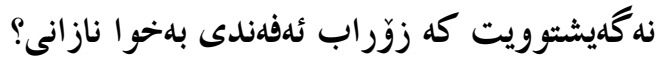
دووباره ئهوى تريان وتى:

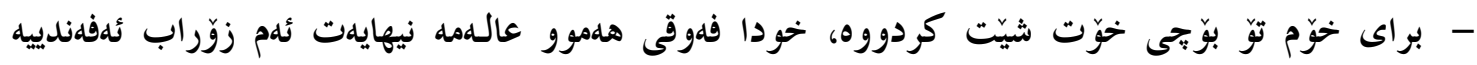

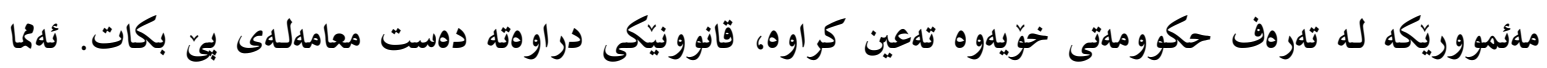

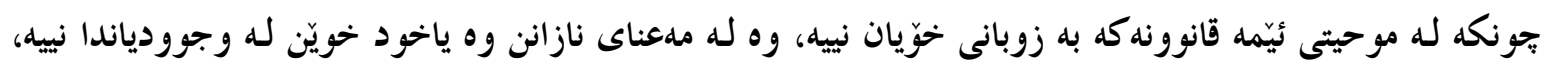

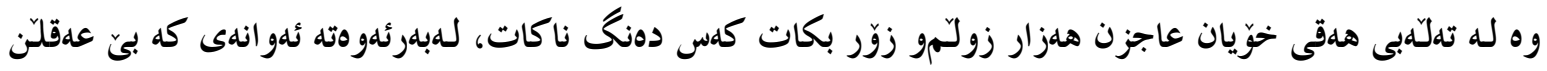

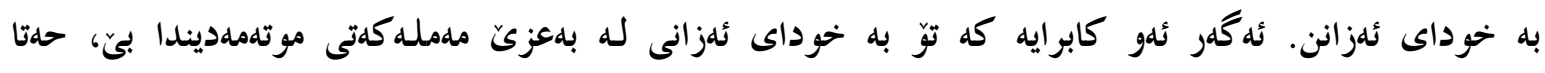
حلماليشيى دهست ناكهويتت. تيكرار مندالّه كهى تر وتى:

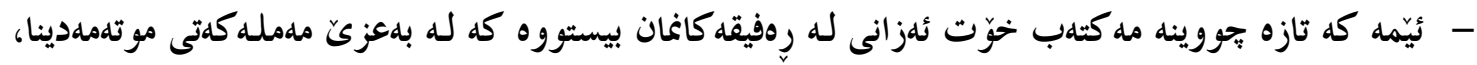

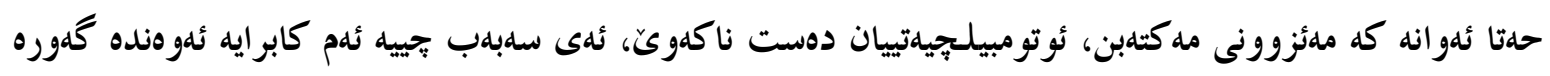
بور؟ 


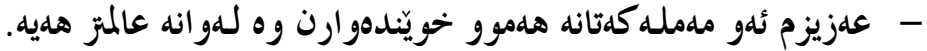

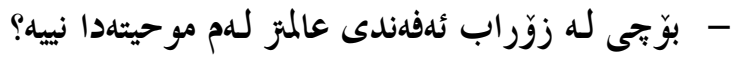

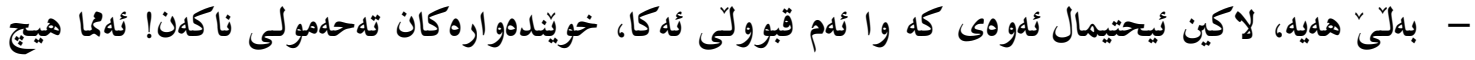

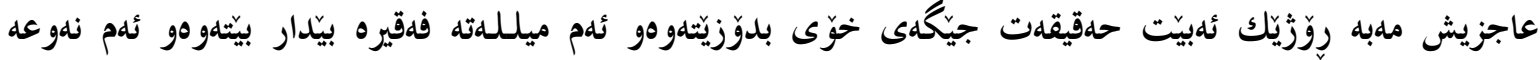

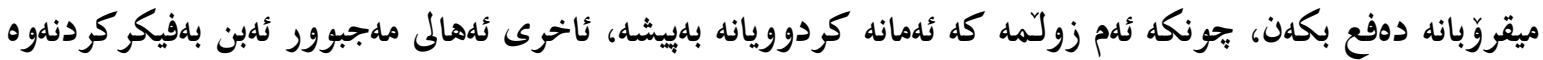

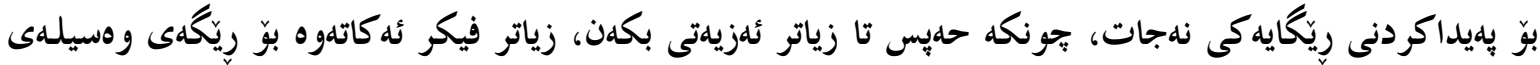

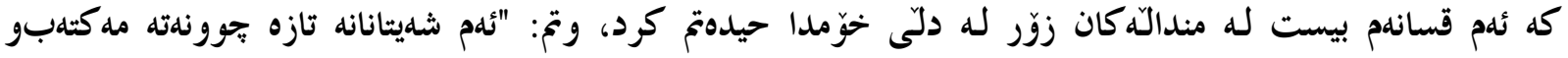

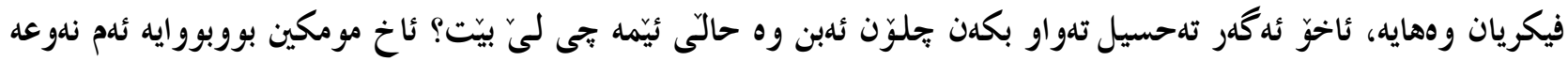

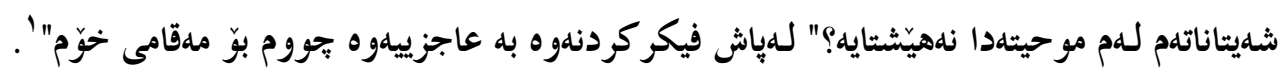

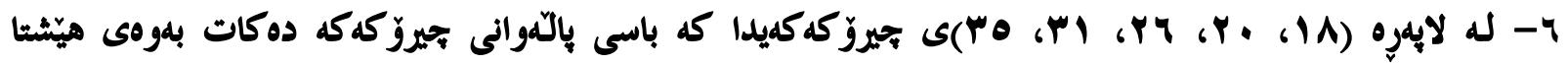

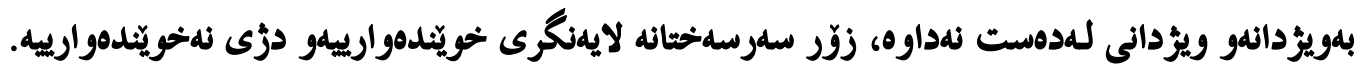

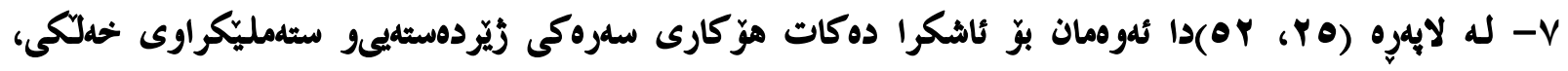

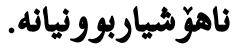

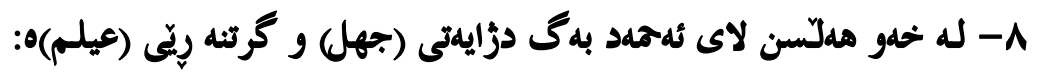

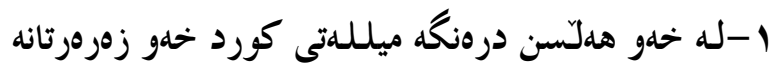
هلمور تلهئريخى عالهم شاهيدى فهزلّو هونهرتانه

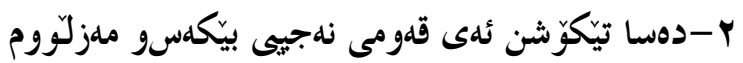

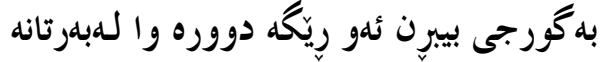

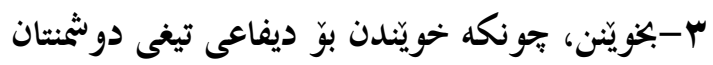
هلموو ئانو زهمانيّ علينى قهلّانو سويهرتانه ع -بلهخوّرايى لله دهستى بلهرمهدهن ئهم خاكه مdحبوربه كه توزّى وهك جلهو اهير سورملوو كوحلى بلهسهرتانه ه-بلهسر خاكا ئه گهر نازيش بكمن حلةقتانه كوردينه تهماشاى سيّبهرى ثئهو شاخِو كيّوه وا للهسهرتانه צ-به بيّ قهدرى بلهسلريا رامهبوورن حورمهتى بكرن

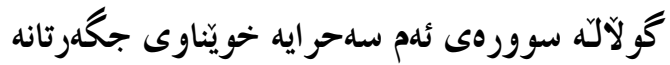

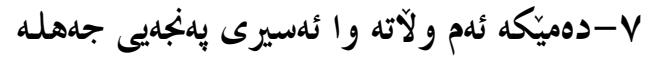




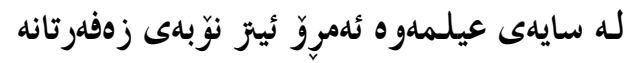

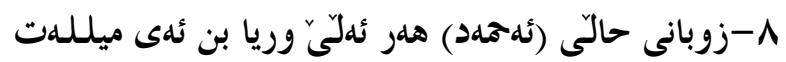

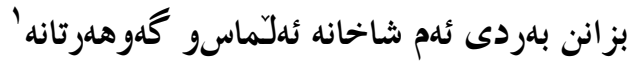

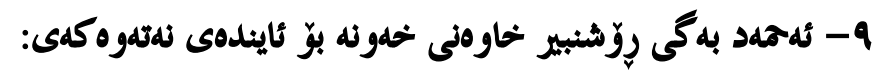

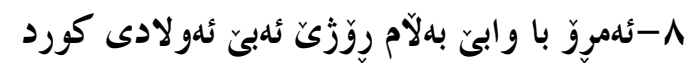

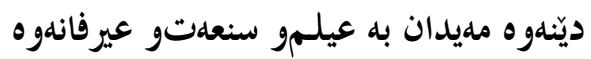

$$
\begin{aligned}
& \text { 9-نهو جو انانى وهتهن تهوحيد ئه كهن ئهم ميللدةته } \\
& \text { هلر له كرماشان هلتا ورمئو سنهو بوَ كانهوه }
\end{aligned}
$$

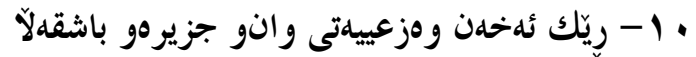

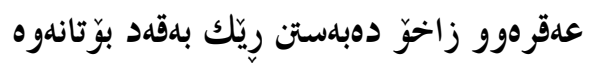

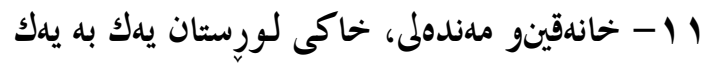$$
\text { ووك ئلهوسا ئهدروون به بالآى مdنيقهى بابانهوه }
$$

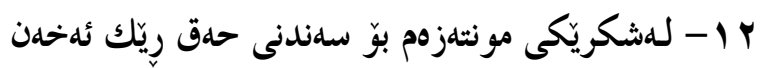

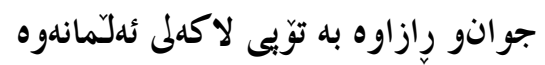

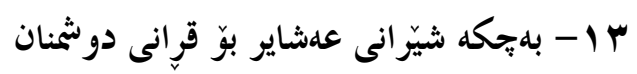

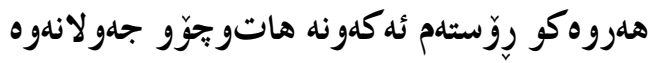

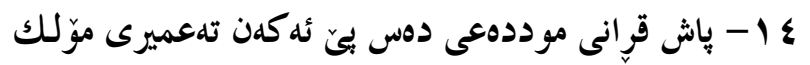

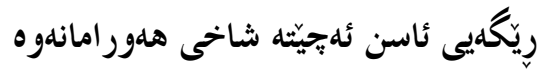$$
10
$$

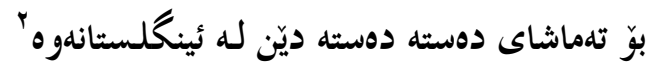

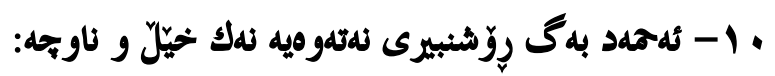

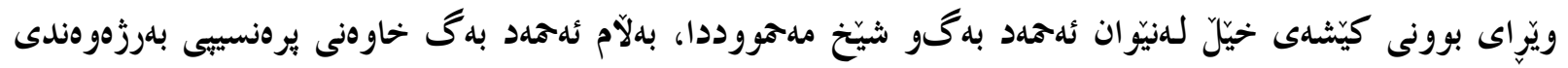

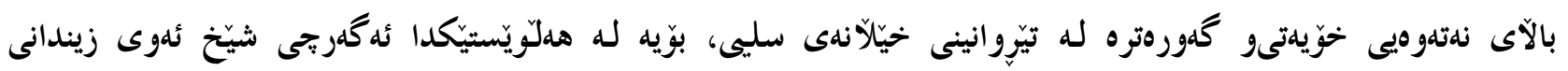

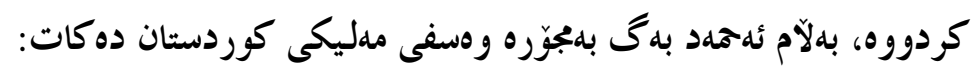

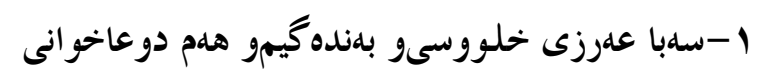

$$
\begin{aligned}
& \text { ببه بوّ خزملتى شاهى موحيتى گشت سولديمانى }
\end{aligned}
$$

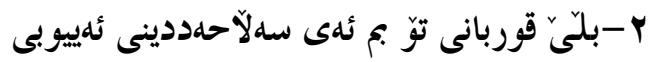




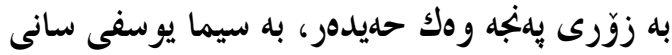

$$
\begin{aligned}
& \text { ب-له دهست كافر نهجاتمان بوو، بيحهمديللاهى وولميننه } \\
& \text { له سايلى دهستو تيغور هيمملتى توّ شيّرى يلزدانى }
\end{aligned}
$$

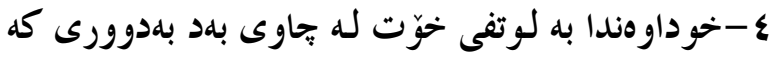

$$
\begin{aligned}
& \text { به جاهى سلييدى مورسهل، به روّحى شاهى گَهيلانى }
\end{aligned}
$$

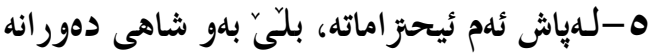

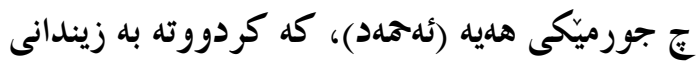

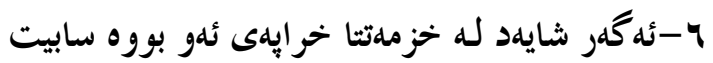

$$
\begin{aligned}
& \text { به لوتفى خوّت علفووى كه جِونكه هدر خوّت ساحيّب ئيحسانى } \\
& \text { V- كه جورميّكى نييه تا كهى، له حلهيسا دانيشيّ قوربان } \\
& \text { له تهنهايى لـه فيكرى جحوّتهوه ئادابى ئينسانى }
\end{aligned}
$$

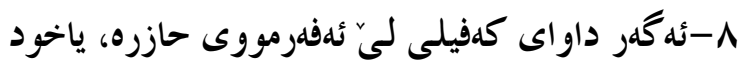

$$
\begin{aligned}
& \text { مولكك تلهئمين ئه كا سهد جار، به ئايينو به ئيمانى } \\
& \text { 9-همتا مردن، وهكو بلنده، له خزمهت شاهى كوردستان } \\
& \text { حلياتى خوّى فيدا كا بَّ هلمورو ئلهريّكَو فهرمانى } \\
& \text { • } 1 \text { - من ئهم حليسهم له لا فهخره، بلشهلرتيّ سهروهرى كوردان }
\end{aligned}
$$

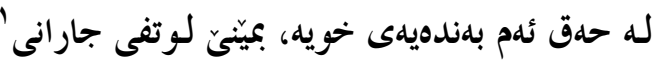

\section{تُهنبام}

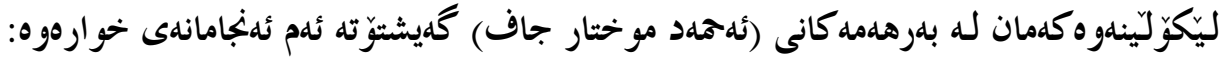

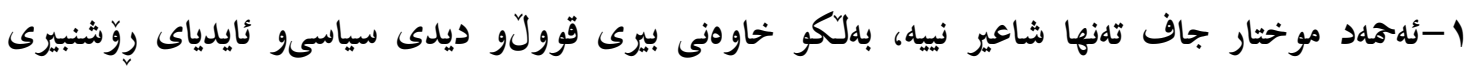

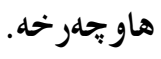

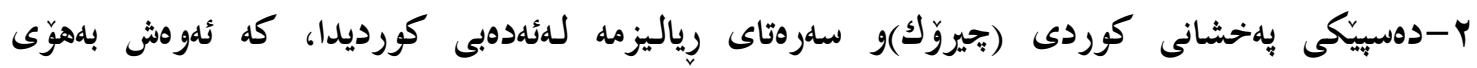

$$
\text { روّ شنبيربورونيهوريه. }
$$

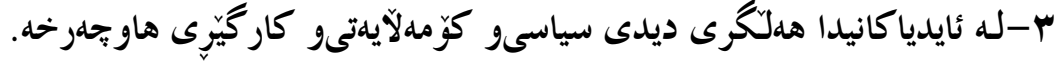

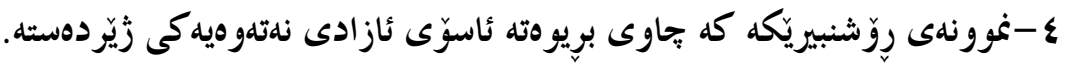

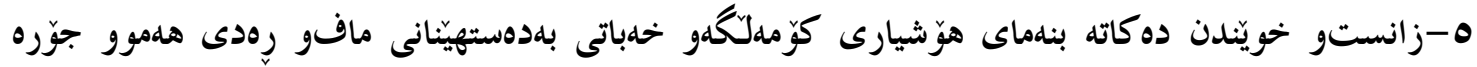

$$
\text { ستdمكارىو توندوتيثييهك ده كاتهوه. }
$$




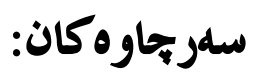

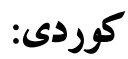

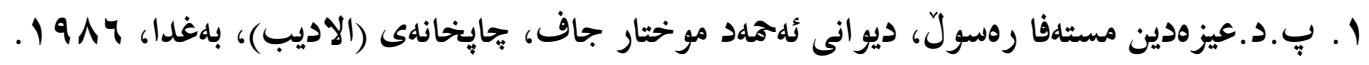

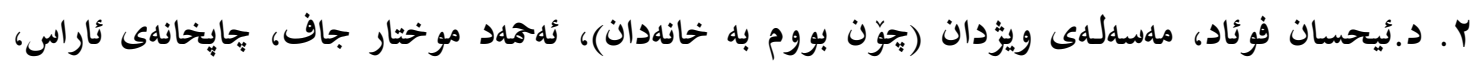

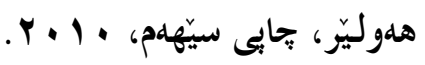

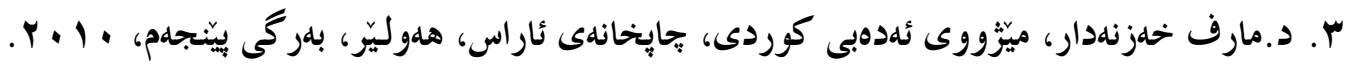

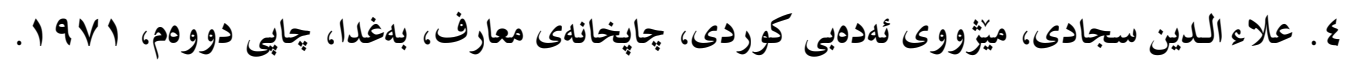

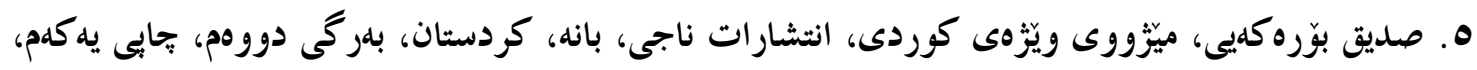

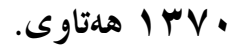

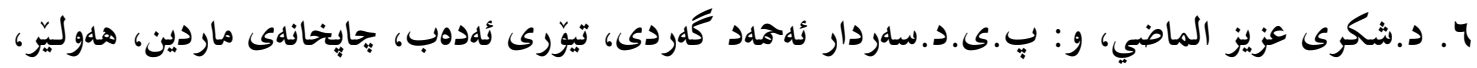
$.1 \cdot$ V. كوّمهلِّكَك نوسهر، ديدارى تايبهت به شاعير ئهمهد موختار جاف، بلاّوكراوهى وهزارهتى رِوْشنبيرىو

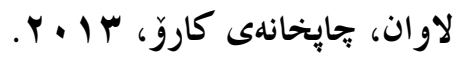

ا. د.عزالدين مصطفى رسول، الواقعية في الأدب الكردي، من منشورات ناراس، الطبعة الثانية، اربيل، $\cdot r \cdot 1 \cdot$

ץ. د.فاروق سعد، تراث الفكر السياسي قبل الأمير وبعده، دار الآفاق الجلديدة، بيروت، الطبعة الرابعة

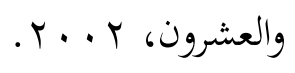

r. سعيد الغانمي، فاعلية الخيال الأدبي، منشورات الجمل، بيروت، 0 ـ ـ . 